\title{
Evidencing the Impact of Coastal Contaminated Sediments on Mussels Through Pb Stable Isotopes Composition
}

\author{
Huy Dang Duc ${ }^{1,2}$, Schaefer Joerg ${ }^{3}$, Brach-Papa Christophe ${ }^{4}$, Lenoble Veronique ${ }^{1}$, Durrieu Gael ${ }^{1}$, \\ Dutruch Lionel ${ }^{3}$, Chiffoleau Jean-Francois ${ }^{4}$, Gonzalez Jean-Louis ${ }^{5}$, Blanc Gerard ${ }^{3}$, \\ Mullot Jean-Ulrich ${ }^{6}$, Mounier Stephane ${ }^{1}$, Garnier Cedric ${ }^{1,{ }^{*}}$
}

${ }^{1}$ Univ Toulon \& Var, PROTEE, EA 3819, F-83957 La Garde, France.

2 Trent Univ, Water Qual Ctr, Peterborough, ON K9J 7B8, Canada.

${ }^{3}$ Univ Bordeaux, UMR EPOC 5805, CS50023, F-33615 Pessac, France.

${ }^{4}$ IFREMER, Ctr Atlantique, LBCM, F-44311 Nantes, France.

${ }^{5}$ IFREMER, Ctr Mediterranee, LBCM, F-83507 La Seyne Sur Mer, France.

${ }^{6}$ LASEM Toulon, F-83800 Toulon, France.

* Corresponding author : Cédric Garnier, email address : cgarnier@univ-tln.fr

\begin{abstract}
:
Heavily contaminated sediments are a serious concern for ecosystem quality, especially in coastal areas, where vulnerability is high due to intense anthropogenic pressure. Surface sediments (54 stations), $50 \mathrm{~cm}$ interface cores (five specific stations), river particles, coal and bulk $\mathrm{Pb}$ plate from past French Navy activities, seawater and mussels were collected in Toulon Bay (NW Mediterranean Sea). Lead content and $\mathrm{Pb}$ stable isotope composition have evidenced the direct impact of sediment pollution stock on both the water column quality and the living organisms, through the specific $\mathrm{Pb}$ isotopic signature in these considered compartments. The history of pollution events including past and present contaminant dispersion in Toulon Bay were also demonstrated by historical records of $\mathrm{Pb}$ content and $\mathrm{Pb}$ isotope ratios in sediment profiles. The sediment resuspension events, as simulated by batch experiments, could be a major factor contributing to the high $\mathrm{Pb}$ mobility in the considered ecosystem. A survey of $\mathrm{Pb}$ concentrations in surface seawater at 40 stations has revealed poor seawater quality, affecting both the dissolved fraction and suspended particles and points to marina/harbors as additional diffuse sources of dissolved $\mathrm{Pb}$.
\end{abstract}




\section{Graphical abstract}

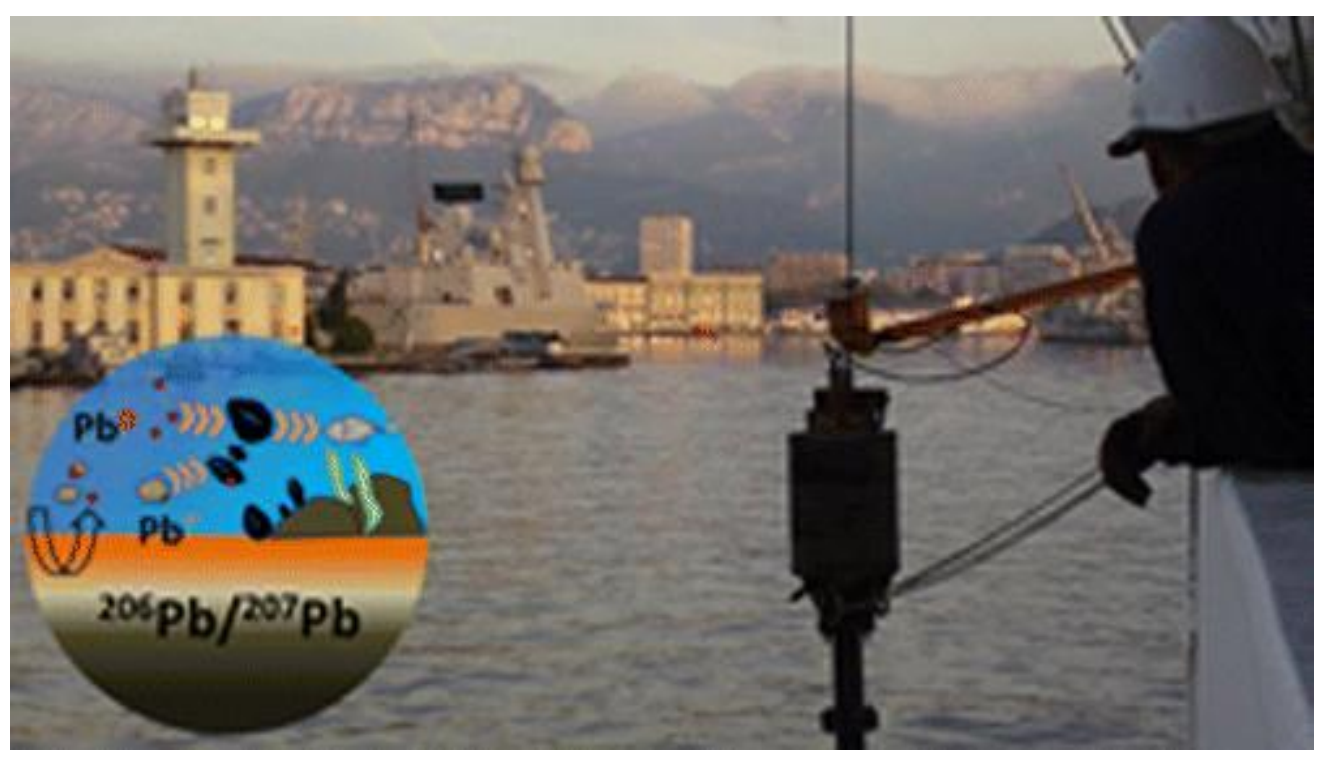




\section{INTRODUCTION}

38 Sources of trace metals in the environment are numerous, either natural or anthropogenic. The principal natural source of metals is crust weathering/erosion while a multitude of anthropogenic emissions occur in the environment (mining/smelting/metal manufacturing, fossil-fuel combustion, urban waste, sewage sludge, etc. ${ }^{1}$ ). Among these metals, $\mathrm{Pb}$ has been widely used for thousands of years (during Estruscan-Greek-Roman, medieval and modern periods ${ }^{2}$ ) due to its low melting point and corrosion resistance. Lead geochemical affinity is chalcophilic, resulting in the predominance of galena $(\mathrm{PbS})$ as the main mineral of economic importance ${ }^{1}$. The four main $\mathrm{Pb}$ stable isotopes are ${ }^{204} \mathrm{~Pb},{ }^{206} \mathrm{~Pb},{ }^{207} \mathrm{~Pb},{ }^{208} \mathrm{~Pb}$ with average proportions of $1: 17: 15: 37{ }^{3,4}$. Except ${ }^{204} \mathrm{~Pb}$ which is not radiogenic, ${ }^{206} \mathrm{~Pb},{ }^{207} \mathrm{~Pb},{ }^{208} \mathrm{~Pb}$ are the radioactive decay products of ${ }^{238} \mathrm{U},{ }^{235} \mathrm{U}$ and ${ }^{232} \mathrm{Th}$, respectively. The $\mathrm{Pb}$ stable isotope ratios are widely used as a source tracking tool in environmental samples ${ }^{2,5,6}$ as well as in organisms ${ }^{7-9}$. Among these organisms, bivalve molluscs and particularly mussels are consensually used as biological monitor organisms of coastal pollution due to their advantageous properties of sedentarity, large spatial distribution, easy sampling and pollutants bioaccumulation ${ }^{7}$. Several "mussel watch programs" (MWP) have been worldwide active for decades (France: RNO/ROCCH ${ }^{8,10}$, Spain ${ }^{7}$, USA ${ }^{11}$, ect.). The most important $\mathrm{Pb}$ sources assessed by $\mathrm{Pb}$ isotope signatures are coal combustion, leaded gasoline, metal smelting, battery factories, sewage sludge and waste incineration ${ }^{1,2}$. Another recent source of metals, including $\mathrm{Pb}$, could be their growing use in antifouling paints ${ }^{12,13}$. In coastal ecosystems, sediments accumulate settling contaminated particles, providing historical archives of pollution ${ }^{14}$. Such sediments could also be a serious concern for the ecosystem quality ${ }^{15}$ due to numerous biogeochemical processes within sediments and at the sediment/water interface (SWI) ${ }^{16-19}$. However, it remains a complex issue to interlink sediment contamination with the

61 degradation of water quality and the living organisms' exposure to pollutants, as a 62 prerequisite for an adapted environmental policy.

63 Toulon Bay (NW Mediterranean sea) sediments are extremely contaminated by a multitude of 64 metals/metalloids/organo-metallics ${ }^{17,20-22}$ and organic contaminants (unpublished data). Such 65 status originated both from historic (bombardments, warship scuttling and -raising during and 66 after the $2^{\text {nd }}$ World War ${ }^{21}$ ) and more recent activities (main French Navy harbor, nautical traffic, release of sewage from the Toulon urban area, industries, tourism...), coupled with its 
characteristics (semi-closed area, low tidal amplitude, long water/particle residence time ${ }^{23}$ ). Analysing data from the MWP, Andral et al. ${ }^{24}$ have observed that Toulon Bay mussels had, by far, the highest $\mathrm{Pb}$ concentrations over $1800 \mathrm{~km}$ of the French Mediterranean coast ( 5.4 $\mu \mathrm{g} \mathrm{g}^{-1}$, dry weight, in comparison to an average value of $\left.1.0(\mathrm{n}=91)\right)$, together with huge anomalies in other pollutants (DDT, CB153, Hg, ...). Trace metals concentrations monitoring both in water and mussel samples from Toulon Bay has shown clear co-variations ${ }^{25}$, even if the origins of high $\mathrm{Pb}$ and $\mathrm{Hg}$ levels still remain unclear. All these observations, associated with the presence of aquaculture activities (fish and mussel farming) inside the bay, raise numerous questions about the potential mobility of such pollutants and further risks for the surrounding environment, making this site a model environment to study such processes which also act in many other areas.

The present study reports on $\mathrm{Pb}$ levels and isotope signatures in sediments, seawater and mussels of the Toulon Bay, focussing on its origins and pathways between these compartments. The objective was to investigate whether the historical sediment $\mathrm{Pb}$ pollution together with resuspension cycles may explain the exceptionally high $\mathrm{Pb}$ contamination in both farmed and wild mussels. Lead concentrations and isotope ratios were measured in (i) total and $1 \mathrm{M}-\mathrm{HCl}$ extracts of surface sediments $(0-5 \mathrm{~cm})$ and $50-\mathrm{cm}$ interface sediment cores, (ii) farmed mussels from the RNO/ROCCH sample bank covering the 1979-2012 period and wild mussels collected in the most contaminated area, (iii) particles issued from small tributaries and hazardous material (coal block and battleship's bulk $\mathrm{Pb}$ plate from French Navy) and (iv) surface seawater samples around the Toulon Bay. Finally, resuspension experiments with surface/deep sediments covering a wide range of $\mathrm{Pb}$ contamination levels aimed at studying $\mathrm{Pb}$ behaviour and remobilisation kinetics.

\section{MATERIALS AND METHODS}

\subsection{Study site and sampling}

The Toulon Bay hosts a large urban area on the French NW Mediterranean coast where various anthropogenic activities (Navy/civil harbours, aquaculture, urban sewage release, industries...) have resulted in severe multi-contamination of the ecosystem, especially in sediments ${ }^{17,20-22}$. The bay is divided by a seawall (N-S straight line, Fig. 1) in two non- 
equivalent parts (Small and Large Bay). Two urban river outlets (Las and Eygoutier Rivers) represent the main freshwater inputs to the bay, located on the north shore, whereas the main anthropogenic activities cover large areas around the Toulon Bay (Fig. 1). In these two tributaries (Las and Eygoutier Rivers), particle traps ${ }^{26,27}$ were installed by IRSN (Radioprotection and Nuclear Safety Institute) to assess the terrestrial contribution to the coastal system. Five particles samples were collected in each tributary using 2 weeks collection periods from October 2012 and May 2013, mostly during rain events ${ }^{28}$.

The studied sediments were collected at 54 stations covering the whole bay (Fig. 1) using an interface corer (10-cm diameter and 1-m long Plexiglass ${ }^{\circledR}$ tube) with the support of the French Navy (boats, materials, divers), as detailed elsewhere ${ }^{16,18,20,28}$. Briefly, for each site, duplicate cores were sliced for surface sediments $(0-5 \mathrm{~cm})$ and slices were pooled, homogenized in HDPE 1-L bottles and deep-frozen $\left(-18^{\circ} \mathrm{C}\right)$. Moreover, interface sediment cores $(\sim 50 \mathrm{~cm})$ were sampled at five specific stations (MIS, 3B, 12, 15 and 23, Fig. 1). Only cores with wellpreserved SWI were analysed. The stations MIS and 3B are located in the Navy area, the station 12 is close to a former Navy submarine base and the station 15 is in the aquaculture area. Finally, the station 23 is situated in the Large Bay, in front of the Eygoutier River outlet. The interface cores were sliced with $2 \mathrm{~cm}$ resolution under inert atmosphere $\left(\mathrm{N}_{2}\right)$. Slices were then centrifuged (4000 rpm, $15 \mathrm{~min}$, Sigma 3-18K). Porewater was recovered in a glove-box by filtration (0.2- $\mu \mathrm{m}$ on-line syringe filters, cellulose nitrate, Sartorius) and stored in the adapted vessels, more details in Dang et al. ${ }^{17}$. The solid fraction was deep-frozen in HDPE bottles, freeze-dried, 2-mm sieved and kept deep-frozen $\left(-18^{\circ} \mathrm{C}\right)$ until analysis.

To evaluate the surface $(0.5 \mathrm{~m})$ distribution of $\mathrm{Pb}$ concentrations in the water column of Toulon Bay, water samples were collected at 40 stations covering the whole bay in early summer (June $24^{\text {th }}, 2013$ ) and winter (February $\left.17^{\text {th }}, 2014\right)$. For each station, raw (unfiltered) and on-field filtered $(0.2 \mu \mathrm{m}$ cellulose nitrate syringe filter, Sartorius) seawater samples were stored in 125-mL FEP bottles (Nalgene), previously acid-cleaned (10\% $\mathrm{HNO}_{3}$, pro analysis), thoroughly rinsed with $\mathrm{mQ}$ water $\left(18.2 \mathrm{M} \Omega\right.$, Millipore) and acid-conditioned $\left(0.1 \% \mathrm{HNO}_{3}\right.$, s.p., Merck) before being rinsed with raw/filtered water from the site. Raw and filtered samples were then acidified $\left(0.2 \%, \mathrm{HNO}_{3}\right.$, s.p., Merck) and digested for $24 \mathrm{~h}$ under UV irradiation $\left(150 \mathrm{~W}^{29}\right)$ to assess the dissolved and total acid-leachable (hereafter considered as "total") concentrations, respectively. Additional surface water $(0.5 \mathrm{~m})$ was sampled in 2-L 
130 HDPE pre-cleaned bottles at 6 stations the $21^{\text {st }}$ of October 2013 (Fig. 1) to analyse Pb isotopic 131 signature.

132 Farmed mussels (35-65 mm, Mytilus galloprovincialis) were sampled in the aquaculture area 133 close to the station 15 within the framework of the RNO/ROCCH program since 1979 134 (seasonally until 2002 and twice a year (February and November) since 2003). Wild mussels 135 were sampled in 2014 at station MIS, 12 and close to Milhaud dock (Fig. 1). The mussels (at 136 least 50) were depurated for $24 \mathrm{~h}$ in a polyethylene aquarium filled with filtered seawater 137 from the station. The soft tissues were separated from shells, pooled, freeze-dried and deep138 frozen $\left(-20^{\circ} \mathrm{C}\right)$.

139 During the dredging operations started in 2013 in the area around the station 3B, huge 140 quantity of coal blocks were discovered in sediments. The inscribed signs ("Anzin, 1912", 141 Fig. S1) illustrated its origin (North of France) and the period. An aliquot was crushed and 142 burned out at $550{ }^{\circ} \mathrm{C}$. The powder was digested on a hot plate with $\mathrm{HCl} / \mathrm{HNO}_{3}$ solution at 110 $143{ }^{\circ} \mathrm{C}$ until complete acid evaporation before dilution with $\mathrm{HNO}_{3}$ (s.p, Merck) for $\mathrm{Pb}$ 144 concentration and $\mathrm{Pb}$ isotopes analysis.

145 Finally, a bulk $\mathrm{Pb}$ plate $\left(\sim 0.5 \mathrm{~m}^{2}\right.$, Fig. $\left.\mathrm{S} 1\right)$ originating from the French Navy battleship 146 "Magenta", sunk in 1876 in the North of Toulon Bay, was collected by Navy divers in April 1472015 from the battleship's beaching area (at $15 \mathrm{~m}$ depth, near the Toulon Navy harbour 148 entrance). Aliquots were cut up, and then submitted to the same protocol as coal powder for $149 \mathrm{~Pb}$ isotope analysis.

151 2.2. Sediment and mussel samples analysis

152 Pseudo-total element contents in sediments and tributaries particles were measured after aqua 153 regia/microwave digestion according to a previously described protocol ${ }^{21,29}$ and validated 154 using PACS-2 certified materials (National Research Council of Canada; accuracy between 1550.9 and $7 \%$ according to the considered element ${ }^{21,29}$. $\mathrm{HCl}$ extraction (1M HCl, s.p. Merck) 156 was performed to assess the potential bioavailability and mobility of major and trace elements $157 \quad 17,29,31$.

158 Farmed mussels (dried powder of Mytilus galloprovincialis) were taken from the French 159 national mussel watch programme sample bank (RNO/ROCCH; IFREMER). Aliquots (150 $160200 \mathrm{mg}$ ) were digested with $8 \mathrm{~mL}$ of $\mathrm{HNO}_{3}$ (ultrapure), in a microwave oven (MARS-5, CEM 
161 Corporation), equipped with a carousel holding 12 Teflon vessels and under temperature and

162 pressure control. After cooling, digests were diluted to $50 \mathrm{~mL}$ with $\mathrm{mQ}$ water.

163 Lead concentrations in semi-total and $1 \mathrm{M}-\mathrm{HCl}$ extracts of sediments (108 from surface 164 cartography, 184 from interface cores, 10 tributary particles) were analyzed by High 165 Resolution Inductively Coupled Plasma Mass Spectrometer at RBI-Zagreb laboratory (HR 166 ICP-MS, Element 2, Thermo Finnigan, more details in Lenoble et al. ${ }^{32}$ ).

167 Stable $\mathrm{Pb}$ isotopes $\left({ }^{206} \mathrm{~Pb},{ }^{207} \mathrm{~Pb},{ }^{208} \mathrm{~Pb}\right)$ were measured by quadrupole ICP-MS on (1) a 168 representative set of sediments samples (34 surface sediments, 70 from interface cores (53 169 semi-total and $171 \mathrm{M}-\mathrm{HCl}$ extracts), 10 tributary particles) at EPOC laboratory-Bordeaux 170 (XSeries 2, ThermoScientific, more details are presented by Petit et al. ${ }^{33}$ ); and on (2) mussels 171 extracts at LBCP-IFREMER laboratory (Element X series, Thermo Electron Corporation). 172 Mass bias and instrumental drift were corrected with a standard bracketing method by 173 analyzing NIST SRM-981 standard reference material. The ${ }^{207} \mathrm{~Pb} /{ }^{206} \mathrm{~Pb}$ and ${ }^{208} \mathrm{~Pb} /{ }^{206} \mathrm{~Pb}$ 174 internal relative standard deviation were in the range of $0.16-0.24 \%(\mathrm{n}=192)$ and $0.10-0.16 \%$ $175(\mathrm{n}=10)$ for sediments and mussels analysis, respectively.

176

$177 \quad 2.3$. Seawater sample analysis

178 Total and dissolved $\mathrm{Pb}$ concentrations in seawater samples were determined by Differential 179 Pulse Anodic Stripping Voltammetry (DPASV). More details on instruments and analytical 180 procedure are described elsewhere ${ }^{34}$. Iron and Mn concentrations in water samples from 181 sediment resuspension experiments (see part 2.4) were measured by HR ICP-MS (RBI 182 laboratory).

183 Seawater samples for $\mathrm{Pb}$ isotopes analysis were filtered $(0.45 \mu \mathrm{m}$, polycarbonate, Nucleopore) 184 under nitrogen pressure. Filtrates were acidified $\left(0.1 \% \mathrm{HNO}_{3}\right.$ s.p.) and stored in polyethylene 185 double-bags protected bottles. Quantitative $\mathrm{Pb}$ extraction from the seawater matrix was 186 performed by dithiocarbamate chelation, extraction into an immiscible organic solution and 187 back-extraction with diluted $\mathrm{HNO}_{3}$ following an adapted protocol of Danielsson et al. ${ }^{35}$, as 188 described by Chiffoleau et al. ${ }^{36}$. In brief, a sample aliquot $(400-500 \mathrm{~g})$ was buffered to $\mathrm{pH}$ 1895.5 with ammonium acetate (s.p.) solution. APDC/DDDC chelating solution was then added 190 and shaken to homogenize. Freon was added next and vigorously shaken. After phase 191 separation, the Freon phase was carefully collected. This Freon extraction step was repeated 
twice. The collected organic phase was then treated with $0.5 \mathrm{~mL} \mathrm{HNO}_{3}$ (s.p.) and $2 \mathrm{~mL} \mathrm{mQ}$ water to degrade the dithiocarbamate chelates. After vigorous shaking and phase separation, the aqueous phase was collected. $1 \mathrm{~mL}$ of the extract was diluted to $5 \mathrm{~mL}$ with $\mathrm{mQ}$ water. Stable $\mathrm{Pb}$ isotope ratios were measured according to the same procedure as mussel samples. In addition, ICP measurements of the procedural blanks was verified to reach values around $500 \mathrm{cps}\left({ }^{208} \mathrm{~Pb}\right)$, when samples were adjusted (by dilution) to $\sim 100000 \mathrm{cps}$. The blank signal only accounted for less than $1 \%$ of the sample signal.

\subsection{Sediment resuspension experiments}

In order to assess the potential of $\mathrm{Pb}$ mobilization during sediment resuspension events (e.g. storm, boat traffic, dredging ...), laboratory experiments were performed using sediments from various sites presenting a large range of contamination. Sediment cores from stations MIS, 3B, 12 and 15 were sliced under $\mathrm{N}_{2}$ conditions, and aliquots of surface/suboxic $(0-2 \mathrm{~cm}$, stations MIS, 3B, 12 and 15) and deep/anoxic (20-22 and 30-32 cm for stations 3B and MIS, respectively) sediments were kept under inert atmosphere until the start of resuspension experiments. To ensure close replication of natural conditions no pre-treatment (e.g. seawater filtering or UF irradiation, autoclaving, poisoning, ...) of the sediment or seawater was performed. However, more detailed experimentation would be necessary to delineate the roles of the various components (e.g., microbes, DOM, minerals, ...).

The solid/liquid (S/L) ratio was setup to $\sim 1 \mathrm{~g} \mathrm{~L}^{-1}$ (expressed in dry weight), a value close to in-situ levels of SPM measured during surface sediment reworking (personal data). Sediment aliquots were then transferred into pre-cleaned 2 L FEP bottles (Nalgene), and filled with the corresponding unfiltered surface $(0.5 \mathrm{~m}$ below the surface) seawater from each sampling station. FEP bottles were then immediately submitted to overhead shaking (15 rpm, Heidolph Reax 20) for 2 weeks. After 10 different contact times (5, 15, 30 min, 1, 3, 7 h, 1, 2 days and 1, 2 weeks), agitation was stopped for few minutes to allow particles settling, then $50 \mathrm{~mL}$ aliquots (or $250 \mathrm{~mL}$ at $1 \mathrm{~h}, 7 \mathrm{~h}$ and $2 \mathrm{w}$ ) were sampled from the surface of the supernatant using pre-cleaned syringes and FEP tube, immediately filtered through $0.45 \mu \mathrm{m}$ filters (hydrophilic PTFE, Millex LCR, Millipore), stored in $60 \mathrm{~mL}$ FEP bottles, acidified (0.2\% $\mathrm{HNO}_{3}$, s.p., Merck) and UV-digested as previously described, before dissolved $\mathrm{Pb}, \mathrm{Mn}, \mathrm{Fe}$ concentrations measurement. Lead isotope analysis was performed on aliquots collected at 0 , 
$1,7 \mathrm{~h}$ and 2 weeks of contact time following the procedure described in section 2.3. To minimize $\mathrm{S} / \mathrm{L}$ ratio variations, $50 \mathrm{~mL}$ (or $250 \mathrm{~mL}$ at 1 and $7 \mathrm{~h}$ ) of unfiltered seawater were injected at each sampling time. To maintain stable oxic conditions (i.e. as encountered in the bay water column during sediment resuspension due to dredging or boat traffic), FEP bottles were opened every day for a few minutes during the whole experiment. Parallel resuspension batches were performed in separate HDPE bottles to monitor the daily variations of physicochemical parameters $\left(\mathrm{T}, \mathrm{pH}, \mathrm{Eh}\right.$, dissolved $\mathrm{O}_{2}$ ) using multi-probes (Hach Lange).

\section{RESULTS AND DISCUSSION}

\subsection{Lead distribution and isotopic composition in sediments}

234 Previous studies 17,20-22,29 have evidenced the huge stock of contaminants (inorganic, 235 organometallic and organic) in the northern Small bay and non-negligible levels in the rest of 236 the bay (Fig. 1). Within the broad $\mathrm{Pb}$ content range $\left(15-470 \mu \mathrm{g} \mathrm{g}{ }^{-1}\right)$, the ${ }^{206} \mathrm{~Pb} /{ }^{207} \mathrm{~Pb}$ ratio 237 variation was unexpectedly low (1.156-1.180), with an average value of $1.168 \pm 0.005(\mathrm{n}=34)$. 238 The lowest ${ }^{206} \mathrm{~Pb} /{ }^{207} \mathrm{~Pb}$ ratios (1.156-1.167) occurred in the most contaminated zones (Navy 239 area, former shipyard, La Seyne s/Mer harbour) and the highest ${ }^{206} \mathrm{~Pb} /{ }^{207} \mathrm{~Pb}$ ratios $(\sim 1.174-$ 2401.180 ) occurred in the less contaminated area. Similar results were obtained using ${ }^{206} \mathrm{~Pb} /{ }^{208} \mathrm{~Pb}$, 241 with an average value and variation range of $0.475 \pm 0.001 \quad(\mathrm{n}=34)$ and $0.474-0.478$, 242 respectively (Table 1$)$. The $\mathrm{Pb} 1 \mathrm{M}-\mathrm{HCl}$ extractability was similar, close to $64 \pm 6 \%$ ( $\mathrm{n}=50)$, for 243 all the stations ${ }^{29}$ and the $\mathrm{Pb}$ isotopic composition of $1 \mathrm{M}-\mathrm{HCl}$ extracts was identical to that of $244 \mathrm{~Pb}$ in total digestions $(\mathrm{n}=10)$.

245 Total $\mathrm{Pb}, \mathrm{HCl}$-extracted $\mathrm{Pb}$ content and $\mathrm{Pb}$ stable isotopes depth profiles from 5 stations 246 (MIS, 3B, 12, 15 and 23) are shown in Fig. 2 and A.1 and compared to previously published $247 \mathrm{~Pb}$ depth profiles from stations $3 \mathrm{~B}, 12$ and $15^{21,29}$. At stations MIS and $3 \mathrm{~B}$, the observed $\mathrm{Pb}$ 248 contents were extremely high all down the cores (380-1300 and 201 $\pm 29 \mu \mathrm{g} \mathrm{g}^{-1}$, respectively) 249 with the majority in the $\mathrm{HCl}$-extracted fraction ( $\sim 80 \pm 8 \%$ at station $3 \mathrm{~B})$. Such deep extension 250 of $\mathrm{Pb}$ contamination, corresponding to an incoherent period of time if considering a stable 251 sedimentation rate estimated around $0.2 \mathrm{~cm} \mathrm{yr}^{-1}$ for the whole bay ${ }^{21}$ are probably the 252 consequence of sediment disturbance due to past (raising of scuttled warships) and present 253 (e.g. harbour extension) activities. In these sediments, the ${ }^{206} \mathrm{~Pb} /{ }^{207} \mathrm{~Pb}$ and ${ }^{206} \mathrm{~Pb} /{ }^{208} \mathrm{~Pb}$ ratios, 
254 either in the total or the HCl-extracted fraction, were stable and close to the values 255 encountered in surface sediments (Fig. 2, Fig. S2, Table 1). Both high Pb contamination and specific $\mathrm{Pb}$ isotope ratios in different parts of the Toulon Bay support the idea that the $\mathrm{Pb}$ sedimentary contamination at the scale of the bay mainly originates from a main source, situated in the military area, mainly linked to past events $\left(2^{\text {nd }}\right.$ World War) and resulting from the multiplicity of $\mathrm{Pb}$ uses by Navy (e.g. weapons, batteries, hull protection, weights, antifouling, explosive, ...). Hereafter, the $\mathrm{Pb}$ stock with ${ }^{206} \mathrm{~Pb} /{ }^{207} \mathrm{~Pb}$ and ${ }^{206} \mathrm{~Pb} /{ }^{208} \mathrm{~Pb}$ values $\left(1.165 \pm 0.004\right.$ and $0.475 \pm 0.001(\mathrm{n}=14)$, respectively) is called ${ }^{\text {anthropogenic }} \mathrm{Pb}$ (Table 1).

At station 12, a strong contamination peak occurred for many pollutants $(\mathrm{Ag}, \mathrm{Cd}, \mathrm{Cu}, \mathrm{Hg}, \mathrm{Pb}$, $\mathrm{Zn}, \mathrm{Sn}, \Sigma \mathrm{BT}$ ) at $-11 \mathrm{~cm}^{20,21,29}$ (Fig. 2). Deeper, smaller peaks at $-25,-40$ and $-50 \mathrm{~cm}$ were hypothetically attributed to a partial burying of contaminated sediment due to nautical/harbour activities ${ }^{21}$. The present $\mathrm{Pb}$ isotope signatures undoubtedly confirm these hypotheses: the main multi-contamination peak has the typical ${ }^{\text {anthropogenic }} \mathrm{Pb}$ signature, similar to that of deeper peaks. Between these small peaks, the non-negligible Pb burdens (70-110 $\mu \mathrm{g} \mathrm{g}^{-1}$, Fig. 2) in deeper sediment layers show slightly higher ${ }^{206} \mathrm{~Pb} /{ }^{207} \mathrm{~Pb}$ and ${ }^{206} \mathrm{~Pb} /{ }^{208} \mathrm{~Pb}$ ratios, i.e. values closer to the natural signature ( ${ }^{\text {natural }} \mathrm{Pb}, 1.195 \pm 0.014$ and $0.483 \pm 0.003(\mathrm{n}=16)$, respectively, Table 1 and A.1). Concerning the $\mathrm{HCl}$-extracted fraction, a similar ${ }^{206} \mathrm{~Pb} /{ }^{207} \mathrm{~Pb}$ ratio and a slightly lower ${ }^{206} \mathrm{~Pb} /{ }^{208} \mathrm{~Pb}$ ratio were recorded in surface sediments compared to deep sediments. In parallel, the $\mathrm{HCl}$-extracted $\mathrm{Pb}$ percentage increased from $\sim 22 \pm 6 \%(\mathrm{n}=7)$ in the

274 Stations 15 and 23 showed similar depth profiles of $\mathrm{Pb}$ content and isotope ratios (Fig. 2 and 275 Fig. S2). Surface layers $(0-15 \mathrm{~cm})$ had quasi-constant $\mathrm{Pb}$ contents $\left(92 \pm 6.9\right.$ and $65 \pm 5.4 \mu \mathrm{g} \mathrm{g}^{-1}$, 276 respectively), along with the ${ }^{\text {anthropogenic }} \mathrm{Pb}$ signature. Deeper, both cores displayed decreasing $277 \mathrm{~Pb}$ concentrations along with increasing ${ }^{206} \mathrm{~Pb} /{ }^{207} \mathrm{~Pb}$ and ${ }^{206} \mathrm{~Pb} /{ }^{208} \mathrm{~Pb}$ ratios, reaching the local 278 background of Toulon Bay $\left(\sim 13.6 \mu \mathrm{g} \mathrm{g}^{-1},{ }^{21}\right)$ and typical signature of ${ }^{\text {natural }} \mathrm{Pb}$. Contrarily to the 279 station 12 , the $\mathrm{Pb}$ acid extractability was significantly higher for the surface sediments $(\sim 76 \pm 4$ $280 \%$ ). A similar ${ }^{206} \mathrm{~Pb} /{ }^{207} \mathrm{~Pb}$ ratio and a slightly higher ${ }^{206} \mathrm{~Pb} /{ }^{208} \mathrm{~Pb}$ ratio were observed.

281 The accumulation of ${ }^{\text {anthropogenic }} \mathrm{Pb}$ in the first 10-12 $\mathrm{cm}$ (corresponding to the past 50-70 years 282 ${ }^{21}$ ) at stations 12, 15 and 23 suggests a main common historical pollution event. The dispersion of these $\mathrm{Pb}$ contaminated particles (and associated pollutants ${ }^{20-22}$ ) is probably still a major pollution source for the more distal parts of the bay. This ongoing pollution spreading 
285 is most probably activated by natural (storm, waves, etc.) or anthropogenic (large boat traffic, 286 harbour activities, etc.) resuspension of the contaminated sediments in the north part of 287 Toulon Bay, followed by particles transport-settling-resuspension processes driven by bottom 288 water hydrodynamics ${ }^{23,37}$.

\section{2. $\mathrm{Pb}$ content and source in mussels}

291 The $\mathrm{Pb}$ contents ranged from 2.2 to $18.7 \mu \mathrm{g} \mathrm{g}^{-1}$ in farmed mussels (1979-2012) and from 14.7 292 to $27.8 \mu \mathrm{g} \mathrm{g}^{-1}$ in wild mussels (Fig. 3). These values were much higher than those measured in 293 the same species along the French Mediterranean coast $\left(\sim 1.0 \mu \mathrm{g} \mathrm{g}^{-1}{ }^{24}\right)$, Italian coast $(0.07$ to $2944.2 \mu \mathrm{g} \mathrm{g}^{-1}{ }^{38}$ ) or American coast (low: 0-3 $\mu \mathrm{g}_{\mathrm{Pb}} \mathrm{g}^{-1}$; medium: 4-6 $\mu \mathrm{g}_{\mathrm{Pb}} \mathrm{g}^{-1}$; high: 7-13 $\mu \mathrm{g}_{\mathrm{Pb}} \mathrm{g}^{-1}$ $295^{11}$ ). Except the 1985-1991 period, it appeared that $\mathrm{Pb}$ concentrations in mussels were 296 systematically higher in winter/spring period than summer/fall due to biological dilution 297 during reproduction cycles ${ }^{8}$. Apart from such intra-annual variation, the long-term $\mathrm{Pb}$ 298 accumulation in mussels seemed to slightly decrease, inversely to the ${ }^{206} \mathrm{~Pb} /{ }^{207} \mathrm{~Pb}$ ratio which 299 tended to increase, still being in the range of ${ }^{\text {anthropogenic }} \mathrm{Pb}$ values (Fig. 3). A similar trend was 300 observed for mussels (Mytilus edulis) from other sites along the French Atlantic coast ${ }^{8}$. The ${ }^{206} \mathrm{~Pb} /{ }^{207} \mathrm{~Pb}$ ratio in Toulon Bay mussels $(\sim 1.163 \pm 0.004, \mathrm{n}=31)$ was close to that reported in 302 the literature $\left(\sim 1.167\right.$ in the Norman-Breton Gulf, $\sim 1.161$ in the Seine Estuary $\left.{ }^{8}\right)$. Labonne et 303 al. ${ }^{39}$ have evidenced 3 isotopic domains in Thau Lagoon mussels, corresponding to 3 spatial 304 areas: sea $\left({ }^{206} \mathrm{~Pb} /{ }^{207} \mathrm{~Pb} \sim 1.170-1.176\right)$, harbour $\left({ }^{206} \mathrm{~Pb} /{ }^{207} \mathrm{~Pb} \sim 1.162-1.169\right)$ and coastal 305 runoff/chemical-impacted zones $\left({ }^{206} \mathrm{~Pb} /{ }^{207} \mathrm{~Pb} \sim 1.158-1.161\right)$. This last specific signature 306 corresponded to the ${ }^{\text {anthropogenic }} \mathrm{Pb}$ signal measured in both Toulon Bay sediments and mussels, 307 suggesting that mussels are exposed to similar $\mathrm{Pb}$ source.

308 The observed very high levels of ${ }^{\text {anthropogenic }} \mathrm{Pb}$ in mussels, which equalled or even exceeded 309 the average $\left(\sim 1.4 \pm 0.1 \mu \mathrm{g} \mathrm{g}^{-1}\right)$ and the highest levels $\left(\sim 8.3 \mu \mathrm{g} \mathrm{g}^{-1}\right)$ recorded on a large scale 310 survey of the Western Mediterranean coastal waters ${ }^{40}$, could be of serious concern. The 311 observed $\mathrm{Pb}$ levels often surpassed the French limit for mussel consumption $\left(7.5 \mu \mathrm{g} \mathrm{g}^{-1}\right.$ 41,42 $^{2}$. 312 The common evolution of $\mathrm{Pb}$ isotope signatures encountered in both sediments and mussels 313 from Toulon Bay clearly suggests a close link between these compartments. 
316 Different source-specific $\mathrm{Pb}$ isotope signatures from the literature were plotted to define the 317 domains of variations for the main Pb sources (Table S1; Fig. S3) and the results obtained for 318 Toulon Bay sediments, tributary river particles, coal, battleship's $\mathrm{Pb}$ plate, mussels and 319 surface seawater were then compared to these various sources (Fig. 4). The deeper layers at 320 stations 12,15 and 23 showed ${ }^{\text {natural }} \mathrm{Pb}$ signatures. All the other sediment samples had typical $321{ }^{\text {anthropogenic }} \mathrm{Pb}$ signatures. When compared to literature data (Fig. $4 \mathrm{~A}$ ), this quite characteristic 322 signature $\left({ }^{206} \mathrm{~Pb} /{ }^{207} \mathrm{~Pb} \sim 1.166 \pm 0.003\right.$ and ${ }^{206} \mathrm{~Pb} /{ }^{208} \mathrm{~Pb} \sim 0.475 \pm 0.001, \mathrm{n}=56$, Table 1) is 323 common to the domains of industries (metal refinery), European coal and urban wastes. Such $324 \mathrm{~Pb}$ isotopic ratios were also close to those of ore deposits in Italia $\left({ }^{206} \mathrm{~Pb} /{ }^{207} \mathrm{~Pb} \sim 1.161\right.$; $\left.{ }^{206} \mathrm{~Pb} /{ }^{208} \mathrm{~Pb} \sim 0.474\right)$ and Spain $\left({ }^{206} \mathrm{~Pb} /{ }^{207} \mathrm{~Pb} \sim 1.167 ;{ }^{206} \mathrm{~Pb} /{ }^{208} \mathrm{~Pb} \sim 0.472\right){ }^{4}$. The "Anzin" coal 326 (total $\mathrm{Pb}$ content $\sim 300 \mu \mathrm{g} \mathrm{g}^{-1}$ ) presented a $\mathrm{Pb}$ isotope signature significantly different from ${ }^{\text {anthropogenic }} \mathrm{Pb}$, either as bulk or ash, probably contributing only slightly to the overall $\mathrm{Pb}$ 328 contamination.

329 As the ${ }^{\text {anthropogenic }} \mathrm{Pb}$ signature appeared to significantly differ from that of ${ }^{\text {natural }} \mathrm{Pb}$, it was 330 possible to estimate the contribution of the $\mathrm{Pb}$ contamination in sediments, using a binary 331 mixing model ${ }^{43}$, according to the following equation:

$$
X_{i}=\frac{{ }^{i}\left({ }^{206} \mathrm{~Pb} /{ }^{207} \mathrm{~Pb}\right)-{ }^{\text {natural }}\left({ }^{206} \mathrm{~Pb} /{ }^{207} \mathrm{~Pb}\right)}{\text { anthropogenic }\left({ }^{206} \mathrm{~Pb} /{ }^{207} \mathrm{~Pb}\right)-{ }^{\text {natural }}\left({ }^{206} \mathrm{~Pb} /{ }^{207} \mathrm{~Pb}\right)}
$$

334 where $\mathrm{X}_{\mathrm{i}}$ is the percentage contribution of ${ }^{\text {anthropogenic }} \mathrm{Pb}$ source in sample $\mathrm{i} ;{ }^{\mathrm{i}}\left({ }^{206} \mathrm{~Pb} /{ }^{207} \mathrm{~Pb}\right)$, anthropogenic $\left({ }^{206} \mathrm{~Pb} /{ }^{207} \mathrm{~Pb}\right)$ and ${ }^{\text {natural }}\left({ }^{206} \mathrm{~Pb} /{ }^{207} \mathrm{~Pb}\right)$ are the isotopic signatures in the sample $\mathrm{i}$ and the 336 main identified $\mathrm{Pb}$ sources in Toulon Bay, respectively.

337 The spatial distribution of $X_{i}$ values in surface sediments of the Toulon Bay (Fig. S5) clearly 338 showed the generally dominant contribution of the ${ }^{\text {anthropogenic }} \mathrm{Pb}$ source, being at least of $43 \%$ 339 in the Large Bay and $>99 \%$ in the Small Bay.

340 The $\mathrm{Pb}$ concentrations in particles transported by the Las and Eygoutier Rivers ranged from 834140 and 24-123 $\mu \mathrm{g} \mathrm{g}^{-1}(\mathrm{n}=10)$, respectively. In the most contaminated particles, the $\mathrm{Pb}$ isotope 342 signature was close to that of ${ }^{\text {anthropogenic }} \mathrm{Pb}$. However, the regression line's slope of ${ }^{206} \mathrm{~Pb} /{ }^{208} \mathrm{~Pb}$ 343 over ${ }^{206} \mathrm{~Pb} /{ }^{207} \mathrm{~Pb}$ ratio in particles was higher than that obtained for sediments (Fig. 4A). This 344 observation, in addition to the lower $\mathrm{Pb}$ content in Las particles compared to the Small Bay 12 
sediments suggests that present river-borne continental inputs only partially contribute to the poor quality of Toulon Bay sediments, mainly influenced by past nautical activities. Indeed,

$347 \mathrm{~Pb}$ isotope signature of the "Magenta" French Navy battleship's Pb plate was close to that of ${ }^{\text {anthropogenic }} \mathrm{Pb}$ (Fig. 4A). Even if the contamination of Toulon bay sediments cannot be induced by bulk $\mathrm{Pb}$ originating from a unique battleship sunk in the $19^{\text {th }}$ century, it illustrates the signature of the $\mathrm{Pb}$ which was used by the French Navy and had mostly contributed to the excessive contamination of the bay during the $2^{\text {nd }}$ World War.

352 The slight increase in ${ }^{206} \mathrm{~Pb} /{ }^{207} \mathrm{~Pb}$ ratios in farmed mussels to reach ${ }^{\text {anthropogenic }} \mathrm{Pb}$ value since 353 the 1990s, (Fig. 3) could partly reflect the withdrawal of the contribution of leaded gasoline 354 ( ${ }^{\text {gasoline }} \mathrm{Pb},{ }^{206} \mathrm{~Pb} /{ }^{207} \mathrm{~Pb}=1.084 \pm 0.010$ and ${ }^{206} \mathrm{~Pb} /{ }^{208} \mathrm{~Pb}=0.458 \pm 0.002(\mathrm{n}=9){ }^{43}$, Table 1, A.1) due to the progressive substitution of leaded gasoline in France since the 1990s and its total prohibition in 2000. However, the historical record of $\mathrm{Pb}$ isotope ratios in farmed mussels suggests that the contribution (from atmosphere and tributaries inputs) of ${ }^{\text {gasoline }} \mathrm{Pb}$ (compared to ${ }^{\text {anthropogenic }} \mathrm{Pb}$ using a binary mixing model equation similar to Eq.1) has decreased from $18 \%$ in 1980 s to an extremely low level $(<0.5 \%)$ since 2004 . Accordingly, the observed $\mathrm{Pb}$ isotope signals provided clear evidence that the local ${ }^{\text {anthropogenic }} \mathrm{Pb}$ contamination has always been greatly dominant, even during the period of maximum leaded gasoline use. The extremely high $\mathrm{Pb}$ content (up to $28.8 \mu \mathrm{g} \mathrm{g}^{-1}$ ) and ${ }^{\text {anthropogenic }} \mathrm{Pb}$ isotopic composition (Fig. 3) in wild mussels in the most polluted area highlights the strong exposure and response of filter feeders to sediment contamination. However, the exact pathway between contaminated sediments and mussels did not become obvious, considering the various mechanisms controlling metal absorption by mussels and other bivalves, which can involve (i) direct assimilation of dissolved metals ${ }^{9,44,45}$, (ii) ingestion of metal-contaminated phytoplankton ${ }^{46}$, (iii) ingestion of contaminated particles (e.g. sediments) ${ }^{47}$ or (iv) mixed mechanisms ${ }^{48-50}$.

369 The two mapping campaigns provided a view on the spatial distribution of dissolved $\mathrm{Pb}$ levels 370 in surface water of the Toulon Bay. The dissolved Pb concentrations measured in Winter 2014 371 were up to 29 times greater than those in unpolluted Mediterranean waters $\left(\sim 0.085 \mathrm{nM}^{51}\right)$ and 372 confirmed previous observations ${ }^{25,52}$ showing that Toulon Bay water is strongly contaminated 373 by $\mathrm{Pb}$ (Fig. 5A). The highest $\mathrm{Pb}$ concentrations in surface water occurred in harbour/marina 374 areas (Fig. 5A), coinciding with higher Pb contents in sediments (Fig. 1). Results obtained in 375 summer 2013 (data not shown) displayed similar trends. The total vs. dissolved $\mathrm{Pb}$ 
concentrations (slope $=1.97, \mathrm{r}^{2}=0.86, \mathrm{n}=80$, Fig. S6) showed an equi-repartition of this

377 trace metal between dissolved and particulate fractions $\left(K_{d}\right.$ value $\sim 5 \times 10^{5} \mathrm{~L} \mathrm{~kg}^{-1}$, considering an average SPM concentration of $2 \mathrm{mg} \mathrm{L}^{-1}$ ), confirming its high affinity for particles ${ }^{53,54}$. The 6 surface seawater samples collected at various places of the Toulon Bay (Fig. 1) to assess seawater $\mathrm{Pb}$ isotopic signature covered a representative range of concentrations $(0.2-1.8 \mathrm{nM})$. Their corresponding $\mathrm{Pb}$ isotopic signature $\left({ }^{206} \mathrm{~Pb} /{ }^{207} \mathrm{~Pb} \sim 1.166 \pm 0.002\right.$ and ${ }^{206} \mathrm{~Pb} /{ }^{208} \mathrm{~Pb} \sim$ $0.475 \pm 0.001, \mathrm{n}=6$ ) appeared to fall exactly in that of ${ }^{\text {anthropogenic }} \mathrm{Pb}$ (Fig. 4B). Even if these results did not enable the preferred mussel pathway of $\mathrm{Pb}$ assimilation from dissolved and particulate fractions to be distinguished, common spatial distribution and isotope signals strongly support the existence of a direct link between the $\mathrm{Pb}$ contamination of Toulon Bay's water column and contaminated sediments, which could originate both from trace metals diffusive flux through the SWI ${ }^{29,55}$ or remobilisation during sediment resuspension ${ }^{56}$. The obtained kinetics of $\mathrm{Pb}$ remobilisation during simulated resuspension of different Toulon Bay sediments reveal both common points and sediment-specific responses (Fig. 5B). As expected, the measured physico-chemical parameters $\left(\mathrm{pH}, \mathrm{Eh}, \mathrm{O}_{2} \ldots\right)$ remained stable all along the experiments (data not shown), maintaining oxic conditions, even if a slight acidification was noticeable after a few days (e.g. surface sediment from stations 3B and MIS, Fig. S4). Confirming previous results, $\mathrm{Pb}$ concentrations initially measured at each site (time of $0.01 \mathrm{~h}$, 394 Fig. 5B) reflected the contamination pattern in Toulon Bay's waters as observed during the mapping campaign, following a South-North gradient from 0.40 to $1.65 \mathrm{nM}$ (station 15 and MIS, respectively). From this initial status, resuspension of surface/suboxic sediments (0-2 $\mathrm{cm}$ layer from the 4 stations, characterized by Eh values ranging from -105 to $-2 \mathrm{mV}_{\text {/ENH }}$ ) systematically induced significant $\mathrm{Pb}$ remobilisation, reaching maximal values after a few hours of contact time, probably due to desorption processes ${ }^{57}$. The $\mathrm{Pb}$ release from sediment increased the initial $\mathrm{Pb}$ concentration by up to 5-13 fold, reaching levels as high as $9.9 \mathrm{nM}$ 401 (i.e. 120 fold the level in unpolluted Mediterranean waters ${ }^{51}$ ), although the maximal 402 proportion of mobilized $\mathrm{Pb}$ from the solid fraction remained low $(0.15$ to $0.5 \%, \mathrm{n}=6)$. Deep 403 sediment $(20-22 \mathrm{~cm})$ from station 3B showed quasi-similar behaviour as surface sediments 404 from the same site (Fig. 5B). As previously discussed (section 3.1.), sediments from this area 405 were submitted to reworking and partial mixing, resulting in a burying of the contamination 406 (Fig. S2), and modifying the diagenesis processes, with a sulfidic layer appearing as deep as - 
$40730 \mathrm{~cm}^{17}$. For all these sediments, the rapid $\mathrm{Pb}$ remobilisation was systematically followed by $408 \mathrm{~Pb}$ removal after days to weeks of contact time (Fig. 5B), a behaviour already observed 409 elsewhere ${ }^{13}$. Contrarily, resuspension of the deep/anoxic sediment layer $(30-32 \mathrm{~cm})$ from 410 station MIS induced a first rapid removal until $1 \mathrm{~h}$ of contact time, followed by a continuous 411 remobilisation reaching the highest recorded $\mathrm{Pb}$ level $(22 \mathrm{nM})$. This succession of $\mathrm{Pb}$ 412 remobilisation/removal steps reflects adsorption/desorption and/or co-precipitation/dissolution 413 processes at different scales, which can partly be explained by the variations of the other 414 parameters. For example, the Fig. S4 represents the temporal variations of $\mathrm{pH}$ and dissolved $415 \mathrm{~Pb}, \mathrm{Fe}$ and $\mathrm{Mn}$ concentrations for the surface sediment $(0-2 \mathrm{~cm})$ slurries from stations $3 \mathrm{~B}$ and 416 MIS. The expected, nearly immediate increase in dissolved metal concentrations due to 417 porewater dilution was calculated from measured concentrations in porewater ${ }^{17,28}$ and from 418 sediment porosity. The experimental data support important porewater contribution to the 419 measured dissolved Fe and Mn concentrations in the batch experiment, as suboxic porewater 420 was enriched in $\mathrm{Fe}^{\mathrm{II}}$ and $\mathrm{Mn}^{\mathrm{II}}$, due to reactive $\mathrm{Fe}$ and $\mathrm{Mn}$ (oxy)hydroxides reduction by early 421 diagenesis ${ }^{17}$. If $\mathrm{Fe}$ is rapidly scavenged ( $\left.15 \mathrm{~min}\right)$ due to known fast kinetics of reoxydation 422 and precipitation in oxygenated seawater, Mn remained in dissolved phase for a longer time 423 ( $\sim 7 \mathrm{~h})$ before being removed following the same processes. Such differences in Fe and $\mathrm{Mn}$ 424 precipitation kinetics have already been observed in previous studies ${ }^{58,59}$. Concerning $\mathrm{Pb}$ 425 remobilisation kinetics, the rapid release within $5 \mathrm{~min}$, noticeable in most of the performed 426 experiments (Fig. 5B and A.3), was not due to porewater contribution but could be attributed 427 to a fast solid/liquid repartitioning, describable by a $K_{d}$ partition coefficient ${ }^{60}$. This weakly428 bound $\mathrm{Pb}$ fraction was assumed as the "labile" fraction whose release mechanism was related 429 to cation exchange reactions ${ }^{61}$. Then, $\mathrm{Pb}$ appeared to be continuously released, probably from 430 a more strongly particle-bound fraction ${ }^{61}$ until $\sim 7 \mathrm{~h}$, after which $\mathrm{Mn}$ oxides started to 431 precipitate. As $\mathrm{Mn}$ oxides are known to be efficient $\mathrm{Pb}$ carrying phases in sediments ${ }^{62}, \mathrm{~Pb}$ 432 adsorption onto freshly precipitated $\mathrm{Mn}$ oxyhydroxides could explain the systematic $\mathrm{Pb}$ 433 removal ${ }^{63}$ observed for the longest contact times with all the studied surface sediments (Fig. 434 5B). The noticeable discrepancy observed for the deep/anoxic sediments from station MIS 435 (Fig. 5B) could be attributed to the involvement of sulfidic phases, acting as binding phases 436 prior to be reoxydized within minutes to hours ${ }^{61,62}$. This scenario suggests that $\mathrm{Pb}$ 
precipitated and definitively fixed as diagenetic sulphides in anoxic sediments, could be partially released into the oxic water column within hours or days of resuspension. The $\mathrm{Pb}$ isotopic composition of seawater during MIS sediment resuspension experiments corresponded to that of sedimentary $\mathrm{Pb}$ (Fig. 5B). This observation supports mobility of the sedimentary ${ }^{\text {anthropogenic }} \mathrm{Pb}$ stock being desorbed from particles and the consecutive impact on

442 the ecosystem quality.

443 Therefore, any scenario inducing resuspension of $\mathrm{Pb}$ contaminated surface sediments will lead 444 to a non-negligible $\mathrm{Pb}$ remobilisation, resulting in both increased particulate and dissolved $\mathrm{Pb}$ 445 concentrations in the water column, which can further be transferred to and bio-accumulated 446 by filter feeder organisms such as mussels. In coastal systems such as the Toulon Bay, which 447 are constantly submitted to various forcing and sediment perturbation (e.g. storm/waves, tidal 448 current, bioturbation, ship traffic/trawling, dredging, harbour infrastructure building, ...), such 449 processes are more than probable to play an important role on surface water quality, although 450 it remains difficult to quantify their respective contributions. It is, however, evident from 451 sediment contamination mapping and hydrodynamic studies that resuspension processes 452 actually participate to the export of contaminants to the open sea ${ }^{20,23}$, probably inducing 453 noticeable toxicological/ecological impacts on various marine organisms ${ }^{64-66}$.

454 The obtained results on $\mathrm{Pb}$ distribution in sediments, water and stable $\mathrm{Pb}$ isotopic signatures 455 clearly evidenced the impact of historical pollution and the dispersion of this pollutant stock 456 over the whole bay, together with other accompanying pollutants (e.g. Hg). A specific $457{ }^{\text {anthropogenic }} \mathrm{Pb}$ isotopic signature in the Toulon Bay was revealed $\left({ }^{206} \mathrm{~Pb} /{ }^{207} \mathrm{~Pb} \sim 1.166 \pm 0.003\right.$ 458 and ${ }^{206} \mathrm{~Pb} /{ }^{208} \mathrm{~Pb} \sim 0.475 \pm 0.001$ ), probably resulting from the multiplicity of $\mathrm{Pb}$ sources used 459 by Navy in the last century. Different factors, either natural (storms, waves, bioturbation) or 460 anthropogenic (ship movement, dredging) most probably explain $\mathrm{Pb}$ export (i) to the more 461 distal surface sediments of the bay and also (ii) to other compartments such as water column 462 through remobilisation (as illustrated by sediment resuspension experiments) and biota. The 463 combination of the spatial distribution of $\mathrm{Pb}$ concentrations in surface water and sediments of 464 the Toulon Bay, isotope signatures in water, sediment and mussels and our observations on $\mathrm{Pb}$ 465 release during sediment resuspension clearly supports $\mathrm{Pb}$ transfer between these 466 compartments. This study confirmed the vulnerability of the Toulon Bay ecosystems in 467 particular, and those of many coastal areas worldwide, where $\mathrm{Pb}$ contamination may affect 
468 both ecosystem and Human health, given that Toulon Bay mussels are still consumed, 469 although their $\mathrm{Pb}$ levels equal or exceed European safety thresholds.

470

471

472

473

474

475

476

477

478

479

480

481

482

483

484

485

486

487

488

489

490

491

492

493

494

495

496

497

498

\section{ACKNOWLEDGEMENTS:}

This study was performed in the framework of MerMex-WP3-C3A research program (part of the international IMBER project), CARTOCHIM and CARTOC research programs (funded by "Toulon-Provence-Méditerranée (TPM)", the "Région PACA", and "l'Agence de l'Eau Rhône-Méditerranée et Corse"), PREVENT research program (funded by "Toulon University", "Toulon-Provence-Méditerranée", and the "Conseil Départemental du Var"). The authors acknowledge support from FEDER (Fonds Européen de Développement Régional) and the "Région Aquitaine". The authors wish to thank the French Navy for diving and sampling assistance, Dr. Omanović for HR ICP-MS analysis (RBI, Zagreb, Croatia), Dr. C. Dufresne and Dr. C. Duffa (IRSN, La Seyne s/Mer, France) for tributary particle sampling and conditioning, Dr. B. Oursel (IMBE, Marseille, France) for sampling assistance. The authors wish to thank the 3 anonymous reviewers for their helpful comments.

\section{SUPPORTING INFORMATION}

Table $\mathrm{S} 1$ : The $\mathrm{Pb}$ stable isotope ratios $\left({ }^{206} \mathrm{~Pb} /{ }^{207} \mathrm{~Pb}\right.$ and $\left.{ }^{206} \mathrm{~Pb} /{ }^{208} \mathrm{~Pb}\right)$ of different $\mathrm{Pb}$ sources Figure S1: Photos of coal block and bulk Pb plate from the "Magenta" French Navy battleship Figure $\mathrm{S} 2 \mathrm{~Pb}$ stable isotope ratios and $\mathrm{Pb}$ content depth profiles at stations $3 \mathrm{~B}$ and 23 Figure $\mathrm{S} 3:{ }^{206} \mathrm{~Pb} /{ }^{208} \mathrm{~Pb}$ ratio as a function of ${ }^{206} \mathrm{~Pb} /{ }^{207} \mathrm{~Pb}$ for various $\mathrm{Pb}$ sources

Figure S4: Time variation of $\mathrm{pH}$, dissolved $\mathrm{Pb}, \mathrm{Fe}$ and $\mathrm{Mn}$ concentrations released during sediment resuspension

Figure S5: Contribution of ${ }^{\text {anthropogenic }} \mathrm{Pb}$ source of Toulon Bay's surface sediments

Figure S6: Relationship observed between the total and dissolved $\mathrm{Pb}$ at 40 stations around Toulon bay

This information is available free of charge via the Internet at http://pubs.acs.org/ 


\section{REFERENCES}

500 (1) Callender, E. Heavy Metals in the Environment - Historical Trends. In Treatise on Geochemistry; Turekian, K. K., Holland, H. D., Eds.; Elsevier Ltd, 2003; Vol. 5, pp $67-105$.

503

504

505

506

507

508

509

510

511

512

513

514

515

516

517

518

519

520

521

522

(2) Elbaz-Poulichet, F.; Dezileau, L.; Freydier, R.; Cossa, D.; Sabatier, P. A 3500-year record of $\mathrm{Hg}$ and $\mathrm{Pb}$ contamination in a mediterranean sedimentary archive (the Pierre Blanche Lagoon, France). Environ. Sci. Technol. 2011, 45, 8642-8647.

(3) Reimann, C.; Caritat, P. Chemical Elements in the Environment; Springer, Berlin, 1998.

(4) Hopper, J. F.; Ross, H. B.; Sturge, W. T.; Barrie, L. A. Regional source discrimination of atmospheric aerosols in Europe using the isotopic composition of lead. Tellus 1991, $43 B, 45-60$.

(5) Monna, F.; Othman, D. Ben; Luck, J. Pb isotopes and Pb, Zn and Cd concentrations in the rivers feeding a coastal pond (Thau, southern France): constraints on the origin (s) and flux (es) of metals. Sci. Total Environ. 1995, 166, 19-34.

(6) Cossa, D.; Buscail, R.; Puig, P.; Chiffoleau, J.-F.; Radakovitch, O.; Jeanty, G.; Heussner, S. Origin and accumulation of trace elements in sediments of the northwestern Mediterranean margin. Chem. Geol. 2014, 380, 61-73.

(7) Besada, V.; Manuel Andrade, J.; Schultze, F.; José González, J. Monitoring of heavy metals in wild mussels (Mytilus galloprovincialis) from the Spanish North-Atlantic coast. Cont. Shelf Res. 2011, 31, 457-465.

(8) Couture, R.-M.; Chiffoleau, J.-F.; Auger, D.; Claisse, D.; Gobeil, C.; Cossa, D. Seasonal and decadal variations in lead sources to eastern North Atlantic mussels. Environ. Sci. Technol. 2010, 44, 1211-1216. 
(9) Bollhöfer, A. Stable lead isotope ratios and metals in freshwater mussels from a uranium mining environment in Australia's wet-dry tropics. Appl. Geochemistry 2012, $27,171-185$.

(10) Claisse, D. Chemical contamination of French coasts: the results of a ten years mussel watch. Mar. Pollut. Bull. 1989, 20, 217-218.

(11) Kimbrough, K. L.; Johnson, W. E.; Lauenstein, G. G.; Chrstensen, J. D.; Apeti, D. A. An assessment of two decades of contaminant monitoring in the nation's coastal zone. Silver Spring, MD. NOAA Technical Memorandum NOS NCCOS 74; Silver Spring, MD, 2008.

(12) Turner, A. Marine pollution from antifouling paint particles. Mar. Pollut. Bull. 2010, $60,159-171$.

(13) Turner, A. Mobilisation and bioaccessibility of lead in paint from abandoned boats. Mar. Pollut. Bull. 2014, 89, 35-39.

(14) Karuppiah, M.; Gupta, G. Chronological changes in toxicity of and heavy metals in sediments of two Chesapeake Bay tributaries. J. Hazard. Mater. 1998, 59, 159-166.

(15) Louriño-Cabana, B.; Lesven, L.; Charriau, A.; Billon, G.; Ouddane, B.; Boughriet, A. Potential risks of metal toxicity in contaminated sediments of Deûle river in northern France. J. Hazard. Mater. 2011, 186, 2129-2137.

(16) Rigaud, S.; Radakovitch, O.; Couture, R.-M.; Deflandre, B.; Cossa, D.; Garnier, C.; Garnier, J.-M. Mobility and fluxes of trace elements and nutrients at the sedimentwater interface of a lagoon under contrasting water column oxygenation conditions. Appl. Geochemistry 2013, 31, 35-51.

(17) Dang, D. H.; Tessier, E.; Lenoble, V.; Durrieu, G.; Omanović, D.; Mullot, J.-U.; Pfeifer, H.-R.; Mounier, S.; Garnier, C. Key parameters controlling arsenic dynamics in coastal sediments: an analytical and modeling approach. Mar. Chem. 2014, 161, 34-46. 
(18) Lesven, L.; Lourino-Cabana, B.; Billon, G.; Recourt, P.; Ouddane, B.; Mikkelsen, O.; Boughriet, a. On metal diagenesis in contaminated sediments of the Deûle river (northern France). Appl. Geochemistry 2010, 25, 1361-1373.

(19) Dang, D. H.; Lenoble, V.; Durrieu, G.; Mullot, J.-U.; Mounier, S.; Garnier, C. Sedimentary dynamics of coastal organic matter: An assessment of the porewater size/reactivity model by spectroscopic techniques. Estuar. Coast. Shelf Sci. 2014, 151, $100-111$.

(20) Pougnet, F.; Schäfer, J.; Dutruch, L.; Garnier, C.; Tessier, E.; Dang, D. H.; Lanceleur, L.; Mullot, J.-U.; Lenoble, V.; Blanc, G. Sources and historical record of tin and butyltin species in a Mediterranean bay (Toulon Bay, France). Environ. Sci. Pollut. Res. Int. 2014, 21, 6640-6651.

(21) Tessier, E.; Garnier, C.; Mullot, J.-U.; Lenoble, V.; Arnaud, M.; Raynaud, M.; Mounier, S. Study of the spatial and historical distribution of sediment inorganic contamination in the Toulon bay (France). Mar. Pollut. Bull. 2011, 62, 2075-2086.

(22) Cossa, D.; Garnier, C.; Buscail, R.; Elbaz-Poulichet, F.; Mikac, N.; Patel-Sorrentino, N.; Tessier, E.; Rigaud, S.; Lenoble, V.; Gobeil, C. A Michaelis-Menten type equation for describing methylmercury dependence on inorganic mercury in aquatic sediments. Biogeochemistry 2014, 119, 35-43.

(23) Dufresne, C.; Duffa, C.; Rey, V. Wind-forced circulation model and water exchanges through the channel in the Bay of Toulon. Ocean Dyn. 2014, 64, 209-224.

(24) Andral, B.; Stanisiere, J. Y.; Sauzade, D.; Damier, E.; Thebault, H.; Galgani, F.; Boissery, P. Monitoring chemical contamination levels in the Mediterranean based on the use of mussel caging. Mar. Pollut. Bull. 2004, 49, 704-712.

(25) Casas, S.; Gonzalez, J.-L.; Andral, B.; Cossa, D. Relation between metal concentration in water and metal content of marine mussels (Mytilus galloprovincialis): impact of physiology. Environ. Toxicol. Chem. 2008, 27, 1543-1552. 
(26) Phillips, J.; Russell, M.; Walling, D. Time-integrated sampling of fluvial suspended sediment: a simple methodology for small catchments. Hydrol. Process. 2000, 14, 2589-2602.

(27) Oursel, B.; Garnier, C.; Pairaud, I.; Omanović, D.; Durrieu, G.; Syakti, a. D.; Le Poupon, C.; Thouvenin, B.; Lucas, Y. Behaviour and fate of urban particles in coastal waters: Settling rate, size distribution and metals contamination characterization. Estuar. Coast. Shelf Sci. 2014, 138, 14-26.

(28) Dufresne, C. Compréhension et analyse des processus hydrosédimentaires dans la baie de Toulon. Apport à la modélisation de la dispersion des radionucléides, Université de Toulon, 2014.

(29) Dang, D. H.; Lenoble, V.; Durrieu, G.; Omanović, D.; Mullot, J.-U.; Mounier, S.; Garnier, C. Seasonal variations of coastal sedimentary trace metals cycling: Insight on the effect of manganese and iron (oxy)hydroxides, sulphide and organic matter. Mar. Pollut. Bull. 2015, 92, 113-124.

(30) Louis, Y.; Garnier, C.; Lenoble, V.; Mounier, S.; Cukrov, N.; Omanović, D.; Pižeta, I. Kinetic and equilibrium studies of copper-dissolved organic matter complexation in water column of the stratified Krka River estuary (Croatia). Mar. Chem. 2009, 114, $110-119$.

(31) Larrose, A.; Coynel, A.; Schäfer, J.; Blanc, G.; Massé, L.; Maneux, E. Assessing the current state of the Gironde Estuary by mapping priority contaminant distribution and risk potential in surface sediment. Appl. Geochemistry 2010, 25, 1912-1923.

(32) Lenoble, V.; Omanović, D.; Garnier, C.; Mounier, S.; Đonlagić, N.; Le Poupon, C.; Pižeta, I. Distribution and chemical speciation of arsenic and heavy metals in highly contaminated waters used for health care purposes (Srebrenica, Bosnia and Herzegovina). Sci. Total Environ. 2013, 443, 420-428.

(33) Petit, J. C. J.; Schäfer, J.; Coynel, A.; Blanc, G.; Deycard, V. N.; Derriennic, H.; Lanceleur, L.; Dutruch, L.; Bossy, C.; Mattielli, N. Anthropogenic sources and 
601

602

603

604

605

606

607

608

609

610

611

612

613

614

615

616

617

618

619

620

621

622

623

624

625

626

biogeochemical reactivity of particulate and dissolved $\mathrm{Cu}$ isotopes in the turbidity gradient of the Garonne River (France). Chem. Geol. 2013, 359, 125-135.

(34) Oursel, B.; Garnier, C.; Durrieu, G.; Mounier, S.; Omanović, D.; Lucas, Y. Dynamics and fates of trace metals chronically input in a Mediterranean coastal zone impacted by a large urban area. Mar. Pollut. Bull. 2013, 69, 137-149.

(35) Danielsson, L.; Magnusson, B. Trace metal determinations in estuarine waters by electrothermal atomic absorption spectrometry after extraction of dithiocarbamate complexes into freon. Anal. Chim. Acta 1982, 144, 183-188.

(36) Chiffoleau, J.; Auger, D.; Boutier, B.; Rozuel, E.; Truquet, I. Dosage de certains métaux dans les sédiments et la matière en suspension par absorption atomique.; Edition Ifremer, 2004.

(37) Duffa, C.; Dufois, F.; Coudray, S. An operational model to simulate post-accidental radionuclide transfers in Toulon marine area: preliminary development. Ocean Dyn. 2011, 61, 1811-1821.

(38) Spada, L.; Annicchiarico, C. Heavy metals monitoring in mussels Mytilus galloprovincialis from the Apulian coasts (Southern Italy). Mediterr. Mar. Sci. 2013, 14, 99-108.

(39) Labonne, M.; Othman, D. Ben; Luck, J. Pb isotopes in mussels as tracers of metal sources and water movements in a lagoon (Thau Basin, S. France). Chem. Geol. 2001, $181,181-191$.

(40) Benedicto, J.; Andral, B.; Martínez-Gómez, C.; Guitart, C.; Deudero, S.; Cento, A.; Scarpato, A.; Caixach, J.; Benbrahim, S.; Chouba, L.; et al. A large scale survey of trace metal levels in coastal waters of the Western Mediterranean basin using caged mussels (Mytilus galloprovincialis). J. Environ. Monit. 2011, 13, 1495-1505.

(41) INERIS. Synthèse des valeurs réglementaires pour les substances chimiques, en vigueur dans l'eau, les denrées alimentaires et dans l'air en France au ler décembre 
2011.; Rapport réalisé pour le Ministère de l'Écologie, du Développement Durable, des Transports et du Logement, Direction Générale de la prévention des risques (DGPR), 2013.

(42) Ifremer. Réseau de suivi lagunaire du Languedoc-Roussillon: Bilan des résultats 2005; Raport RSL-06/2006, 2006.

(43) Monna, F.; Lancelot, J.; Croudace, I. W.; Cundy, A. B.; Lewis, J. T. Pb Isotopic Composition of Airborne Particulate Material from France and the Southern United Kingdom: Implications for Pb Pollution Sources in Urban Areas. Environ. Sci. Technol. 1997, 31, 2277-2286.

(44) Markich, S.; Jeffree, R. Absorption of divalent trace metals as analogues of calcium by Australian freshwater bivalves: an explanation of how water hardness reduces metal toxicity. Aquat. Toxicol. 1994, 29, 257-290.

(45) Roditi, H. A.; Fisher, N. S.; Sañudo-Wilhelmy, S. A. Uptake of dissolved organic carbon and trace elements by zebra mussels. Nature 2000, 407, 78-80.

(46) Wang, W.-X.; Fisher, N. S.; Luoma, S. N. Assimilation of trace elements ingested by the mussel Mytilus edulis:effects of algal food abundance. Mar. Ecol. Prog. Ser. 1995, $129,165-176$.

(47) Gagnon, C.; Fisher, N. S. The bioavailability of sediment-bound Cd, Co, and Ag to the mussel Mytilus edulis. Can. J. Fish. Aquat. Sci. 1997, 54, 147-156.

(48) Ke, C.; Wang, W.-X. Trace metal ingestion and assimilation by the green mussel Perna viridis in a phytoplankton and sediment mixture. Mar. Biol. 2002, 140, 327-335.

(49) Chong, K.; Wang, W. Bioavailability of sediment-bound Cd, Cr and $\mathrm{Zn}$ to the green mussel Perna viridis and the Manila clam Ruditapes philippinarum. J. Exp. Mar. Bio. Ecol. 2000, 255, 75-92. 
(50) Strady, E.; Schafer, J.; Baudrimont, M.; Blanc, G. Tracing cadmium contamination kinetics and pathways in oysters (Crassostrea gigas) by multiple stable $\mathrm{Cd}$ isotope spike experiments. Ecotoxicol. Environ. Saf. 2011, 74, 600-606.

(51) Morley, N. H.; Burton, J. D.; Tankere, S. P. C.; Martin, J.-M. Distribution and behaviour of some dissolved trace metals in the western Mediterranean Sea. Deep Sea Res. Part II Top. Stud. Oceanogr. 1997, 44, 675-691.

(52) Jean, N.; Dumont, E.; Durrieu, G.; Balliau, T.; Jamet, J.-L.; Personnic, S.; Garnier, C. Protein expression from zooplankton communities in a metal contaminated NW mediterranean coastal ecosystem. Mar. Environ. Res. 2012, 80, 12-26.

(53) Botelho, C. M. S.; Boaventura, R. a. R.; Gonçalves, M. L. S. S. Interactions of Pb(II) with particles of a polluted river. Anal. Chim. Acta 2002, 462, 73-85.

(54) Baskaran, M.; Santschi, P. H. The role of particles and colloids in the transport of radionuclides in coastal environments of Texas. Mar. Chem. 1993, 43, 95-114.

(55) Gallon, C.; Tessier, A.; Gobeil, C.; Alfaro-De La Torre, M. Modeling diagenesis of lead in sediments of a Canadian Shield lake. Geochim. Cosmochim. Acta 2004, 68, $3531-3545$.

(56) Caetano, M.; Madureira, M.-J.; Vale, C. Metal remobilisation during resuspension of anoxic contaminated sediment: Short-term laboratory study. Water, Air, Soil Pollut. 2002, 143, 23-40.

(57) Superville, P.-J.; Prygiel, E.; Magnier, A.; Lesven, L.; Gao, Y.; Baeyens, W.; Ouddane, B.; Dumoulin, D.; Billon, G. Daily variations of $\mathrm{Zn}$ and $\mathrm{Pb}$ concentrations in the Deûle River in relation to the resuspension of heavily polluted sediments. Sci. Total Environ. 2014, 470, 600-607.

(58) Morgan, J. J. Kinetics of reaction between $\mathrm{O} 2$ and $\mathrm{Mn}(\mathrm{II})$ species in aqueous solutions. Geochim. Cosmochim. Acta 2005, 69, 35-48. 
(59) Rose, A. L.; Waite, T. D. Kinetics of hydrolysis and precipitation of ferric iron in seawater. Environ. Sci. Technol. 2003, 37, 3897-3903.

(60) Turner, A.; Crussell, M.; Millward, G. E.; Cobelo-Garcia, A.; Fisher, A. S. Adsorption Kinetics of Platinum Group Elements in River Water. Environ. Sci. Technol. 2006, 40, 1524-1531.

(61) Cappuyns, V.; Swennen, R. The application of $\mathrm{pH}($ stat) leaching tests to assess the $\mathrm{pH}-$ dependent release of trace metals from soils, sediments and waste materials. J. Hazard. Mater. 2008, 158, 185-195.

(62) Eggleton, J.; Thomas, K. V. A review of factors affecting the release and bioavailability of contaminants during sediment disturbance events. Environ. Int. 2004, 30, 973-980.

(63) Elbaz-Poulichet, F.; Holliger, P.; Wen Huang, W.; Martin, J.-M. Lead cycling in estuaries, illustrated by the Gironde estuary, France. Nature 1984, 308, 409-414.

(64) Roberts, D. A. Causes and ecological effects of resuspended contaminated sediments (RCS) in marine environments. Environ. Int. 2012, 40, 230-243.

(65) Vale, C.; Ferreira, a; Micaelo, C.; Caetano, M.; Pereira, E.; Madureira, M.; Ramalhosa, E. Mobility of contaminants inrelation to dredging operations in a mesotidal estuary (Tagus Estuary, Portugal). Water Sci. Technol. 1998, 37, 25-31.

(66) Vicente-Martorell, J. J.; Galindo-Riaño, M. D.; García-Vargas, M.; Granado-Castro, M. D. Bioavailability of heavy metals monitoring water, sediments and fish species from a polluted estuary. J. Hazard. Mater. 2009, 162, 823-836. 
701 Table 1: Summary of $\mathrm{Pb}$ contents, ${ }^{206} \mathrm{~Pb} /{ }^{207} \mathrm{~Pb}$ and ${ }^{206} \mathrm{~Pb} /{ }^{208} \mathrm{~Pb}$ ratios in semi-total extracts expressed in average (number of sample) and the variation range (min-max) in surface and cored sediments. The specific $\mathrm{Pb}$ isotope compositions of lead issued from anthropogenic, 704 natural and gasoline sources are presented as ${ }^{\text {anthropogenic }} \mathrm{Pb},{ }^{\text {natural }} \mathrm{Pb}$ and ${ }^{\text {gasoline }} \mathrm{Pb}$. The ${ }^{\text {natural }} \mathrm{Pb}$ 705 and ${ }^{\text {gasoline }} \mathrm{Pb}$ signatures are gathered from literature, see Table $\mathrm{S} 1$ for detailed values and 706 citations.

707

\begin{tabular}{llccc}
\hline & & $\mathrm{Pb}$ content $\left(\mu \mathrm{g} \mathrm{g}{ }^{-1}\right)$ & ${ }^{206} \mathrm{~Pb} /{ }^{207} \mathrm{~Pb}$ & ${ }^{206} \mathrm{~Pb} /{ }^{208} \mathrm{~Pb}$ \\
\hline Surface & Average & $107(\mathrm{n}=54)$ & $1.168(\mathrm{n}=34)$ & $0.475(\mathrm{n}=34)$ \\
& Range (min-max) & $15-467$ & $1.156-1.180$ & $0.474-0.478$ \\
\hline St. MIS & Average & $907(\mathrm{n}=28)$ & $1.164(\mathrm{n}=7)$ & $0.475(\mathrm{n}=7)$ \\
& Range (min-max) & $377-1310$ & $1.156-1.172$ & $0.474-0.476$ \\
\hline St. 3B & Average & $201(\mathrm{n}=23)$ & $1.166(\mathrm{n}=7)$ & $0.475(\mathrm{n}=7)$ \\
& Range (min-max) & $146-265$ & $1.162-1.1700$ & $0.474-0.476$ \\
\hline St. 12 & Average & $179(\mathrm{n}=29)$ & $1.174(\mathrm{n}=29)$ & $0.476(\mathrm{n}=29)$ \\
& Range (min-max) & $70-423$ & $1.165-1.180$ & $0.475-0.479$ \\
\hline St. 23 & Average & $50(\mathrm{n}=28)$ & $1.179(\mathrm{n}=14)$ & $0.478(\mathrm{n}=14)$ \\
& Range (min-max) & $14-118$ & $1.164-1.197$ & $0.475-0.482$ \\
\hline anthropogenic $\mathrm{Pb}$ & Average & $41.9(\mathrm{n}=20)$ & $1.175(\mathrm{n}=7)$ & $0.476(\mathrm{n}=7)$ \\
natural $\mathrm{Pb}$ & Range (min-max) & $15-78$ & $1.165-1.189$ & $0.473-0.478$ \\
gasoline $\mathrm{Pb}{ }^{43}$ & $\mathrm{n}=14$ & & $1.165 \pm 0.004$ & $0.475 \pm 0.001$ \\
\hline & $\mathrm{n}=9$ & & $1.195 \pm 0.014$ & $0.483 \pm 0.003$ \\
\hline
\end{tabular}


Figure 1: Map of the studied site with the main anthropogenic activities and location of the 54 sampled surface $(0-5 \mathrm{~cm})$ sediments (open square), $550-\mathrm{cm}$ interface sediment cores (circle) and 6 seawater samples collected for $\mathrm{Pb}$ isotopes analysis (open diamond). The contour plot represents the total $\mathrm{Pb}$ content in surface sediments.

Figure 2: $\mathrm{Pb}$ stable isotope ratios $\left({ }^{206} \mathrm{~Pb} /{ }^{207} \mathrm{~Pb}\right.$ and ${ }^{206} \mathrm{~Pb} /{ }^{208} \mathrm{~Pb}$, circle and square, respectively) and $\mathrm{Pb}$ content depth profiles (diamond) from $50-\mathrm{cm}$ interface core collected at stations MIS, 12 and 15. The full and open symbols respectively represent total and HCl-extracted fractions. The filled areas with increasing grey scale indicate specific signature of industrial $\mathrm{Pb}$, leaded gasoline and natural $\mathrm{Pb}$, respectively. The full and dashed lines represent the variation range and the average value of the $\mathrm{Pb}$ isotopes ratios recorded in surface sediments $(n=54)$ of Toulon Bay, respectively.

Figure 3: $\mathrm{Pb}$ content in farmed mussels sampled in summer/fall and winter/spring periods (close and open triangle, respectively). The grey diamond, circle and square symbols represent wild mussels sampled in 2014 at stations MIS, 12 and Milhaud dock, respectively. The filled areas represent guideline levels in mussels from American coast ${ }^{11}$. The dotted line represents the range of $\mathrm{Pb}$ content in Mediterranean mussels ${ }^{24,39}$.

734 Figure 4: ${ }^{206 \mathrm{~Pb}} /{ }^{208} \mathrm{~Pb}$ ratio as a function ${ }^{206} \mathrm{~Pb} /{ }^{207} \mathrm{~Pb}$ ratio for (A) Toulon Bay sediments (circles and squares illustrating interface sediment cores and surface sediments, respectively), tributaries particles (cross, symbol size as a function of $\mathrm{Pb}$ total content), "Anzin" coal block (star) and "Magenta" French Navy battleship's Pb plate (hexagone), (B) seawater (blue triangles), mussels (reverse triangles, grey square, circle and diamond) samples in comparison to the range of variation of various $\mathrm{Pb}$ sources from literature (Table S1 and Figure S2). 
742 Figure 5: (A) Dissolved $\mathrm{Pb}$ concentration in surface seawater at 40 stations of Toulon Bay 743 (February 2014). A contour map was generated by kriging method and the scale layers 744 represent the statistical distribution (centiles) of the concentration range. (B) Dissolved $\mathrm{Pb}$ 745 concentration (and ${ }^{206} \mathrm{~Pb} /{ }^{207} \mathrm{~Pb}$ ratio) remobilized during sediments resuspension simulation 746 experiments using sediments from stations MIS, 3B, 12 and 15 as a function of time. Open 747 and close symbols represent surface and deep sediments, respectively (see text for more 748 details). 
Table 1:

\begin{tabular}{llccc}
\hline & & $\mathrm{Pb}$ content $\left(\mu \mathrm{g} \mathrm{g}^{-1}\right)$ & ${ }^{206} \mathrm{~Pb} /{ }^{207} \mathrm{~Pb}$ & ${ }^{206} \mathrm{~Pb} /{ }^{208} \mathrm{~Pb}$ \\
\hline $\begin{array}{l}\text { Surface } \\
\text { sediments }\end{array}$ & Average & $107(34)$ & $1.168(34)$ & $0.475(34)$ \\
& (sample number) & & & \\
& Range (min-max) & $15-467$ & $1.156-1.180$ & $0.474-0.478$ \\
\hline St. MIS & Average & $907(28)$ & $1.164(7)$ & $0.475(7)$ \\
& Range (min-max) & $377-1310$ & $1.156-1.172$ & $0.474-0.476$ \\
\hline St. $3 \mathrm{~B}$ & Average & $201(23)$ & $1.166(7)$ & $0.475(7)$ \\
& Range (min-max) & $146-265$ & $1.162-1.1700$ & $0.474-0.476$ \\
\hline St. 12 & Average & $179(29)$ & $1.174(29)$ & $0.476(29)$ \\
& Range (min-max) & $70-423$ & $1.165-1.180$ & $0.475-0.479$ \\
\hline St. 15 & Average & $50(28)$ & $1.179(14)$ & $0.478(14)$ \\
& Range (min-max) & $14-118$ & $1.164-1.197$ & $0.475-0.482$ \\
\hline $\mathrm{St.} 23$ & Average & $41.9(20)$ & $1.175(7)$ & $0.476(7)$ \\
& Range (min-max) & $15-78$ & $1.165-1.189$ & $0.473-0.478$ \\
\hline${ }_{\text {anthropogenic }} \mathrm{Pb}$ & $\mathrm{n}=14$ & & $1.165 \pm 0.004$ & $0.475 \pm 0.001$ \\
${ }_{\text {natural }} \mathrm{Pb}$ & $\mathrm{n}=16$ & & $1.195 \pm 0.014$ & $0.483 \pm 0.003$ \\
gasoline $\mathrm{Pb}{ }^{43}$ & $\mathrm{n}=9$ & & $1.084 \pm 0.010$ & $0.458 \pm 0.002$ \\
\hline
\end{tabular}


${ }^{206} \mathrm{~Pb} /{ }^{207} \mathrm{~Pb}$

${ }^{206} \mathrm{~Pb} /{ }^{208} \mathrm{~Pb}$

$\mathbf{P b}\left(\mu \mathrm{g} \mathrm{g}^{-1}\right)$

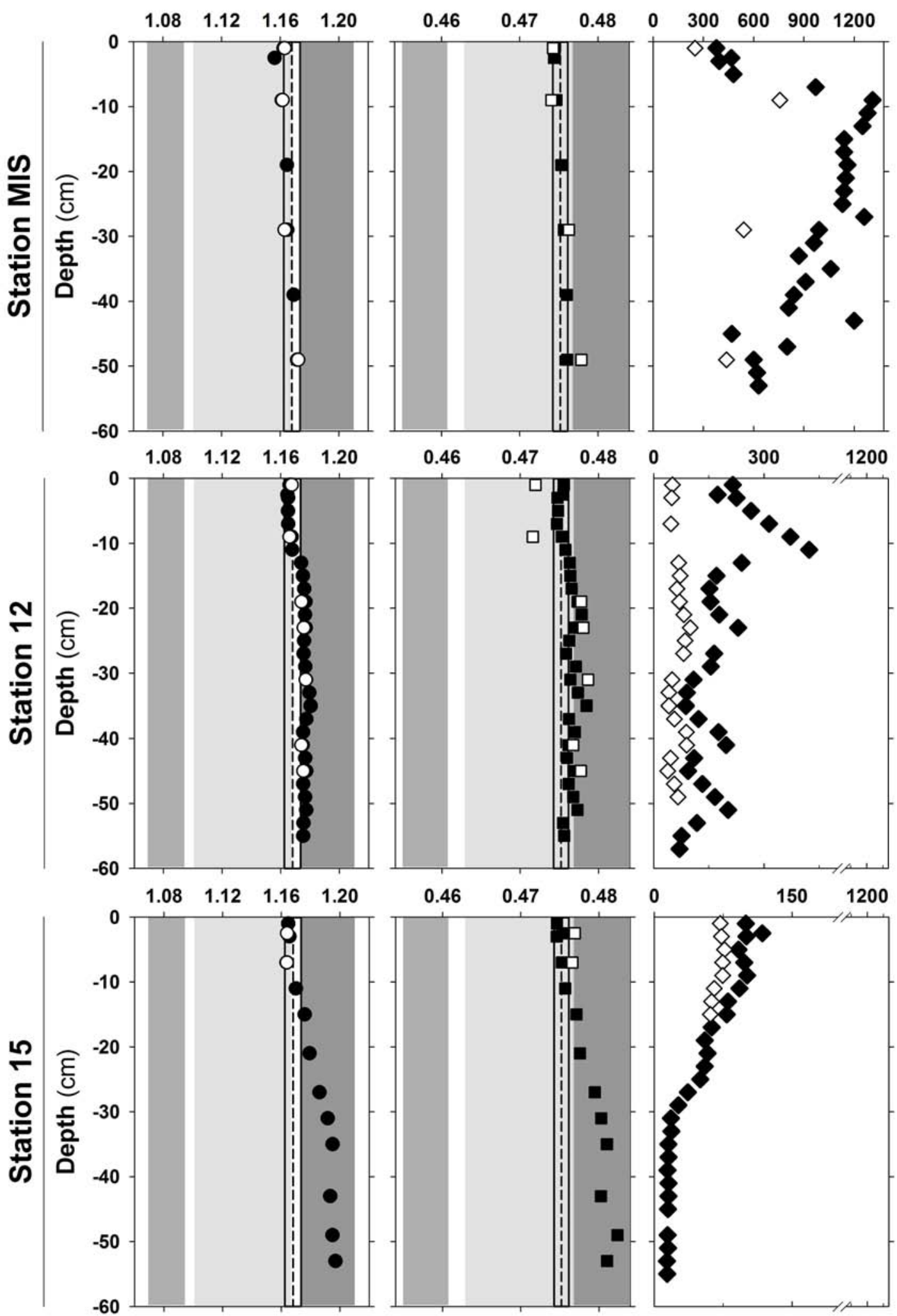

Natural $\mathrm{Pb}$

$\square$ Gasoline $\mathrm{Pb}$

Minimal and maximal $\mathrm{Pb}$ ratio (surface sediments) Mean $\mathrm{Pb}$ ratio (surface sediments) 
- $\mathrm{Pb}$ content range in Mediterranean mussels $\diamond$ Wild mussels at st. MIS

- Farmed mussels (Summer/fall period) $\quad 0$ Wild mussels at st. 12

$\rightarrow-\quad$ Farmed mussels (Winter/spring period) $\quad \square \quad$ Wild mussels at st. Milhaud
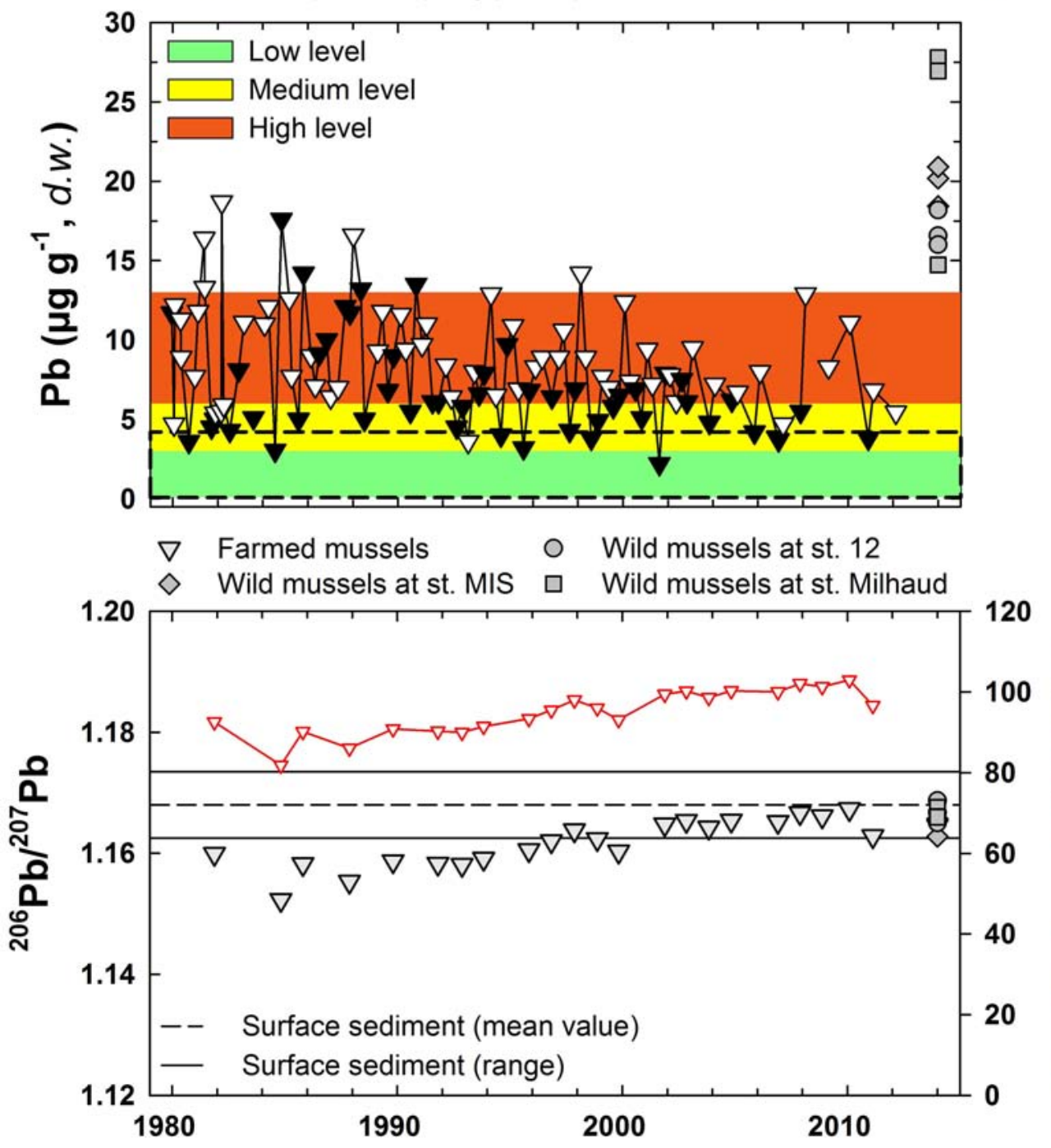


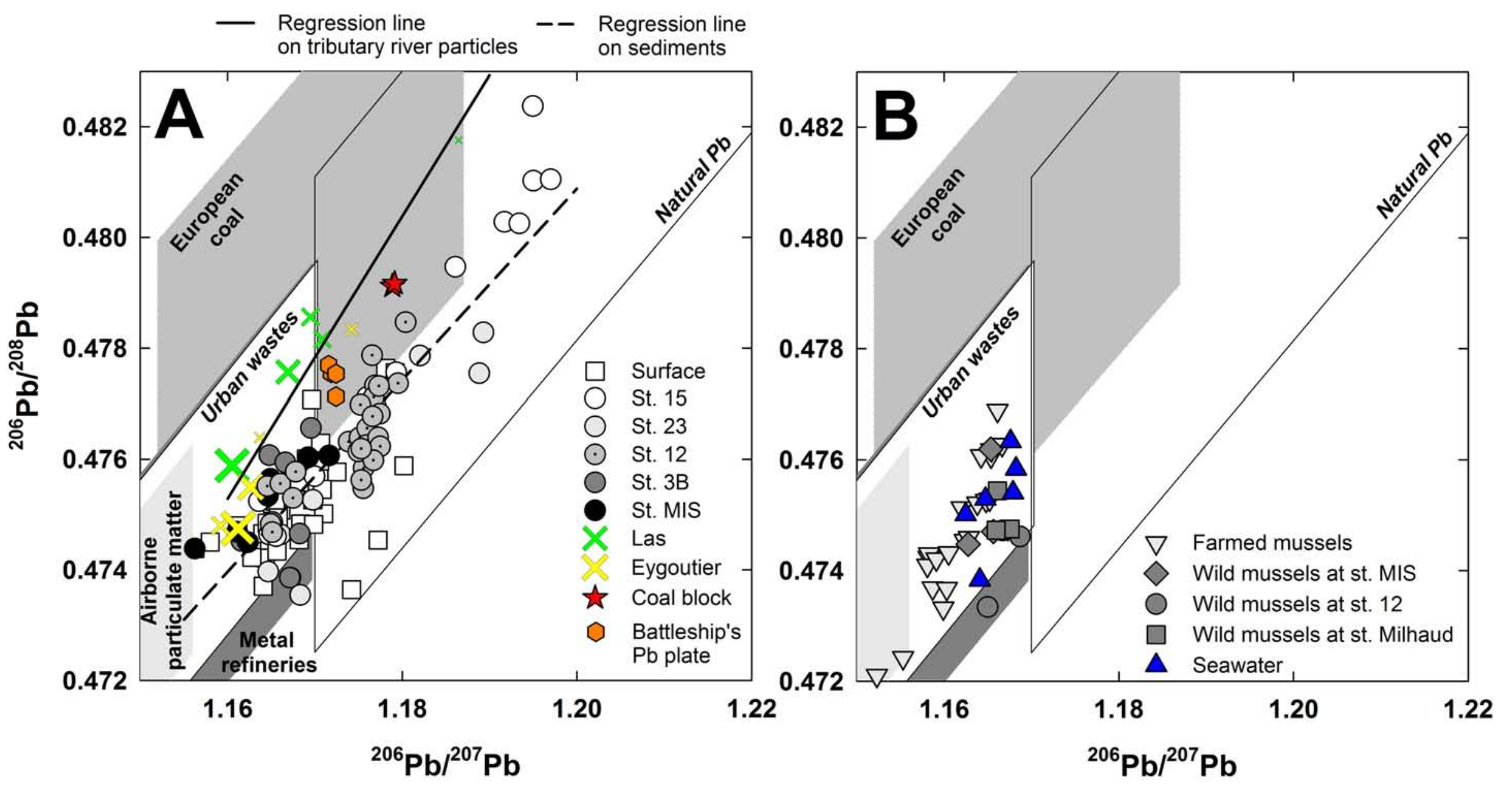




\section{SUPPORTING INFORMATION}

Manuscript Title: Evidencing the impact of coastal contaminated sediments on mussels through $\mathrm{Pb}$ stable isotopes composition

Authors Duc Huy Dang, Jörg Schäfer, Christophe Brach-Papa, Véronique Lenoble, Gaël Durrieu, Lionel Dutruch, Jean-Francois Chiffoleau, Jean-Louis Gonzalez, Gérard Blanc, Jean-Ulrich Mullot, Stéphane Mounier, Cédric Garnier*

*: corresponding author, email: cgarnier@univ-tln.fr

Number of pages: 11 
Table S1: The $\mathrm{Pb}$ stable isotope ratios $\left({ }^{206} \mathrm{~Pb} /{ }^{207} \mathrm{~Pb}\right.$ and $\left.{ }^{206} \mathrm{~Pb} /{ }^{208} \mathrm{~Pb}\right)$ of different $\mathrm{Pb}$ sources

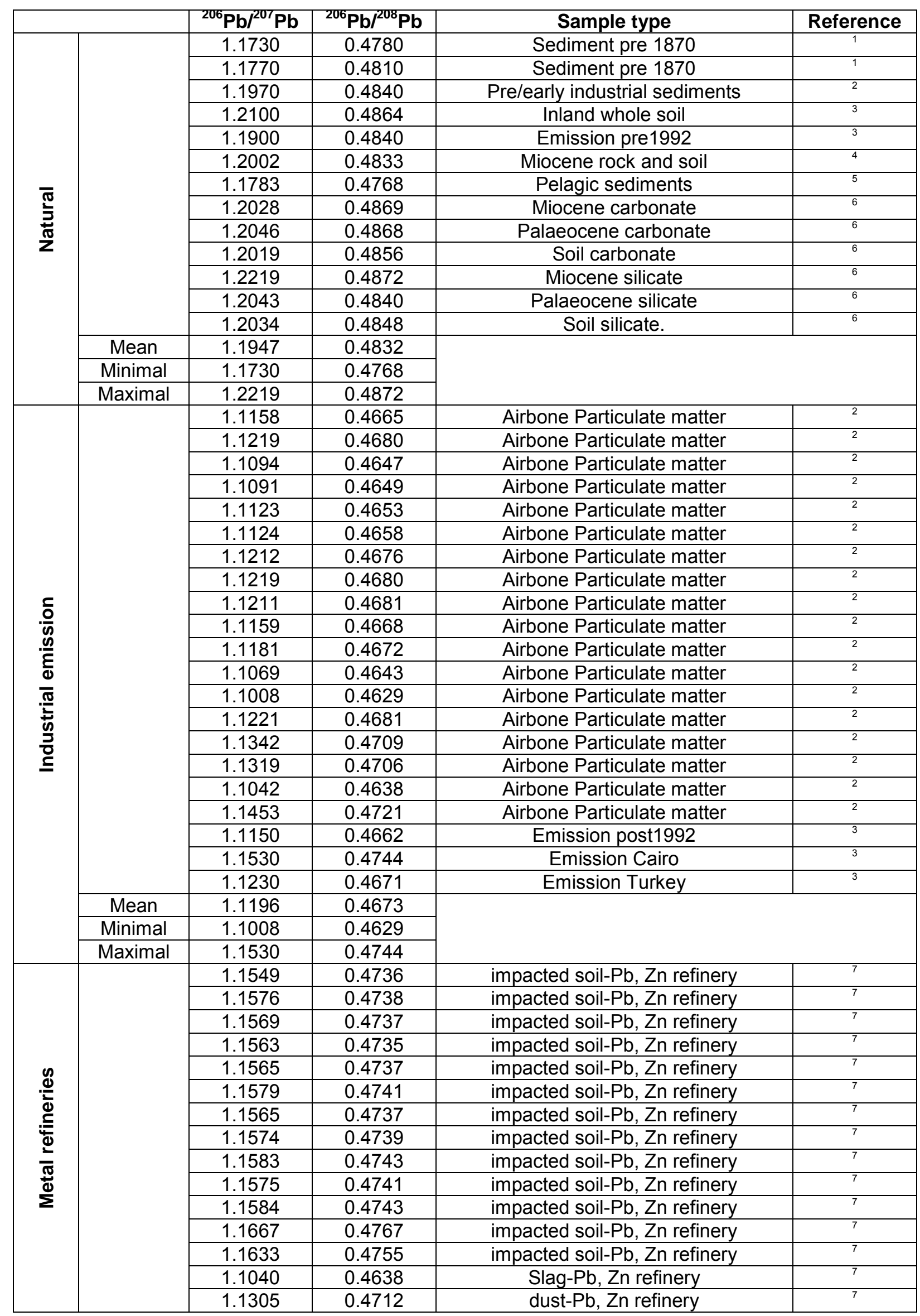




\begin{tabular}{|c|c|c|c|c|c|}
\hline & & 1.1273 & 0.4706 & dust- $\mathrm{Pb}, \mathrm{Zn}$ refinery & \\
\hline & & 1.1176 & 0.4672 & Fe-Mn metallurgy plant & 8 \\
\hline & & 1.1064 & 0.4635 & Fe-Mn metallurgy plant & 8 \\
\hline & & 1.1099 & 0.4643 & Fe-Mn metallurgy plant & 8 \\
\hline & & 1.1336 & 0.4703 & $\begin{array}{l}\text { Lead smelter } \\
\end{array}$ & 8 \\
\hline & & 1.1323 & 0.4700 & Lead smelter & 8 \\
\hline & Mean & 1.1438 & 0.4717 & & \\
\hline & Minimal & 1.1040 & 0.4635 & & \\
\hline & Maximal & 1.1667 & 0.4767 & & \\
\hline \multirow{12}{*}{$\begin{array}{l}\stackrel{0}{\Xi} \\
\overline{0} \\
\mathscr{D} \\
\mathbb{0}\end{array}$} & & 1.0693 & 0.4550 & & 2 \\
\hline & & 1.0806 & 0.4580 & & 2 \\
\hline & & 1.0942 & 0.4604 & & 2 \\
\hline & & 1.0942 & 0.4607 & & 2 \\
\hline & & 1.0753 & 0.4565 & & 2 \\
\hline & & 1.0878 & 0.4592 & & 2 \\
\hline & & 1.0736 & 0.4563 & & 2 \\
\hline & & 1.0856 & 0.4588 & & 2 \\
\hline & & 1.0943 & 0.4602 & & 2 \\
\hline & Mean & 1.0839 & 0.4584 & & \\
\hline & Minimal & 1.0693 & 0.4550 & & \\
\hline & Maximal & 1.0943 & 0.4607 & & \\
\hline \multirow{18}{*}{ 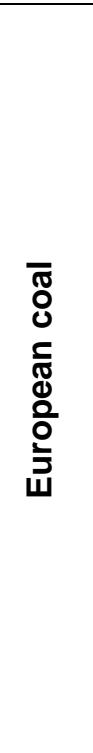 } & & 1.1840 & 0.4799 & & 9 \\
\hline & & 1.1809 & 0.4786 & & 10 \\
\hline & & 1.1675 & 0.4778 & & $\overline{11}$ \\
\hline & & 1.1700 & 0.4776 & & $\overline{12}$ \\
\hline & & 1.1550 & 0.4779 & & 13 \\
\hline & & 1.1800 & 0.4830 & & 14 \\
\hline & & 1.1740 & 0.4820 & & 14 \\
\hline & & 1.1810 & 0.4820 & & 14 \\
\hline & & 1.1710 & 0.4800 & & ${ }^{14}$ \\
\hline & & 1.1710 & 0.4790 & & $\overline{14}$ \\
\hline & & 1.1770 & 0.4820 & & ${ }_{14}^{14}$ \\
\hline & & 1.1820 & 0.4830 & & 14 \\
\hline & & 1.1800 & 0.4830 & & 14 \\
\hline & & 1.1840 & 0.4830 & & 14 \\
\hline & & 1.1820 & 0.4840 & & 14 \\
\hline & Mean & 1.1760 & 0.4808 & & \\
\hline & Minimal & 1.1550 & 0.4776 & & \\
\hline & Maximal & 1.1840 & 0.4840 & & \\
\hline \multirow{9}{*}{ 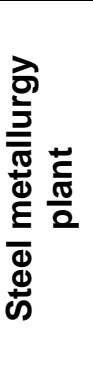 } & & 1.2226 & 0.4991 & & 8 \\
\hline & & 1.2064 & 0.4953 & & 8 \\
\hline & & 1.1944 & 0.4922 & & 8 \\
\hline & & 1.1829 & 0.4886 & & 8 \\
\hline & & 1.1786 & 0.4869 & & 8 \\
\hline & & 1.1897 & 0.4904 & & 8 \\
\hline & Mean & 1.1958 & 0.4921 & & \\
\hline & Minimal & 1.1786 & 0.4869 & & \\
\hline & Maximal & 1.2226 & 0.4991 & & \\
\hline \multirow{10}{*}{ 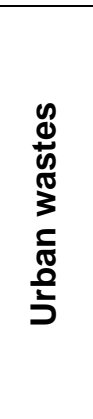 } & & 1.1540 & 0.4742 & French southern cities/villages & 6 \\
\hline & & 1.1620 & 0.4755 & French southern cities/villages & 6 \\
\hline & & 1.1552 & 0.4772 & French southern cities/villages & 6 \\
\hline & & 1.1543 & 0.4734 & French southern cities/villages & 6 \\
\hline & & 1.1673 & 0.4766 & French southern cities/villages & 6 \\
\hline & & 1.1600 & 0.4741 & French southern cities/villages & 4 \\
\hline & & 1.1609 & 0.4738 & French southern cities/villages & ${ }^{4}$ \\
\hline & & 1.1600 & 0.4743 & French southern cities/villages & $\overline{4}$ \\
\hline & & 1.1613 & 0.4752 & French southern cities/villages & 4 \\
\hline & & 1.1547 & 0.4741 & French southern cities/villages & 4 \\
\hline
\end{tabular}




\begin{tabular}{|c|c|c|c|c|}
\hline & 1.1585 & 0.4737 & French southern cities/villages & \\
\hline & 1.1476 & 0.4722 & French southern cities/villages & \\
\hline & 1.1494 & 0.4724 & French southern cities/villages & 4 \\
\hline & 1.1479 & 0.4734 & French southern cities/villages & \\
\hline & 1.1578 & 0.4741 & French southern cities/villages & \\
\hline & 1.1577 & 0.4745 & French southern cities/villages & 4 \\
\hline Mean & 1.1587 & 0.4743 & & \\
\hline Minimal & 1.1476 & 0.4722 & & \\
\hline Maximal & 1.1673 & 0.4772 & & \\
\hline
\end{tabular}




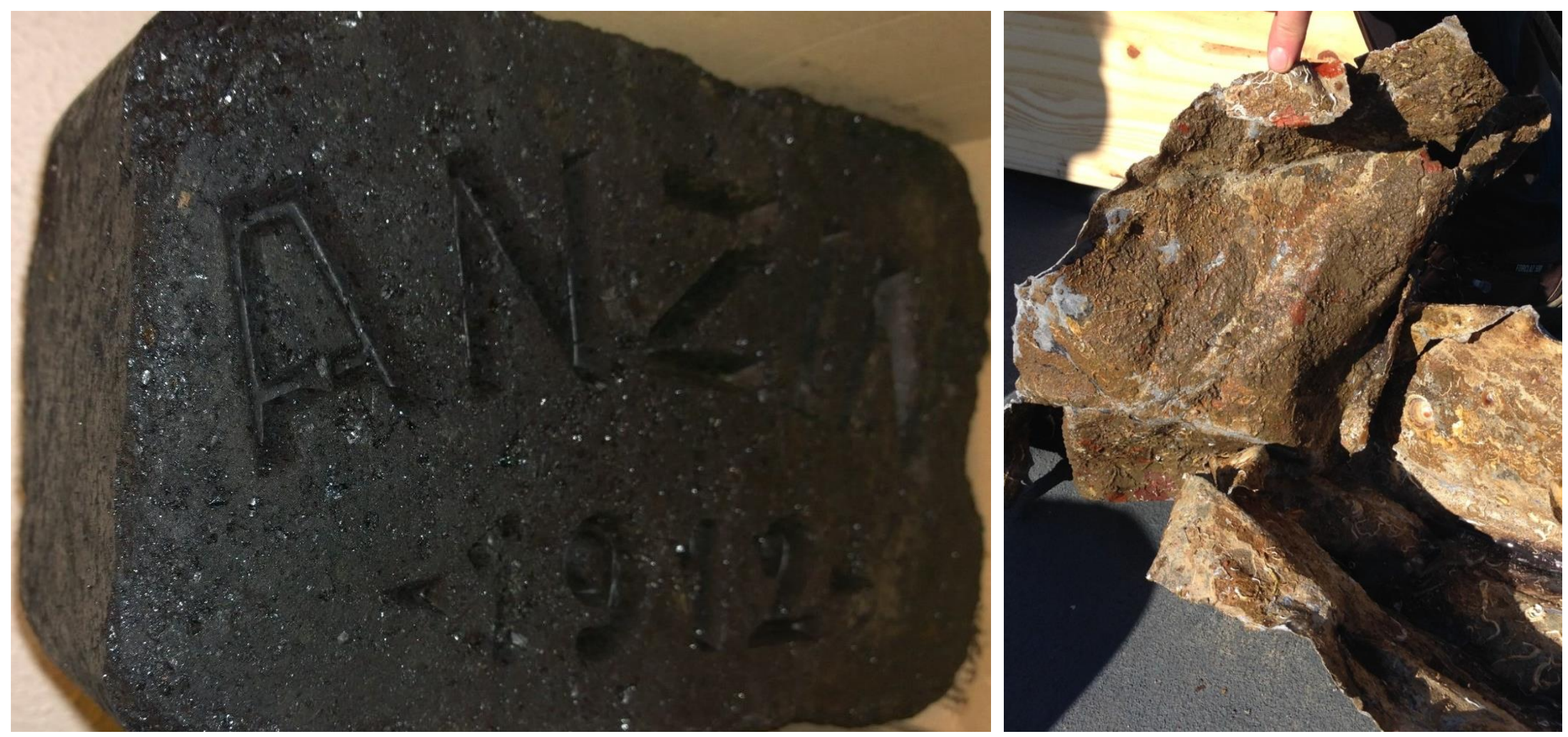

Figure S1: (Left) Coal block found at station 3B during dredging operations (2014) where "Anzin 1912" was inscribed, illustrating its origin (Anzin, North of France) and period. Indeed, blocks of coal were stored and used by the French Navy for its fleets. Up to 400 tons of such blocks were discovered in the area, as it was used as a coal loading dock for French Navy fleet.

(Right) Lead plate from the "Magenta" French Navy battleship, sunk in 1876 in the entrance of Toulon Navy harbour. 
Figure S2: $\mathrm{Pb}$ stable isotope ratios $\left({ }^{206} \mathrm{~Pb} /{ }^{207} \mathrm{~Pb}\right.$ and ${ }^{206} \mathrm{~Pb} /{ }^{208} \mathrm{~Pb}$, circle and square, respectively) and $\mathrm{Pb}$ content depth profiles (diamond) from $50-\mathrm{cm}$ interface core collected at stations $3 \mathrm{~B}$ and 23 . The full and open symbols respectively represent total and $\mathrm{HCl}$-extracted fractions. The filled areas with increasing grey scale indicate specific signature of industrial $\mathrm{Pb}$, leaded gasoline and natural $\mathrm{Pb}$, respectively. The full and dashed lines represent the variation range and the average value of the $\mathrm{Pb}$ isotopes ratios recorded in surface sediments $(n=54)$ of Toulon bay, respectively.

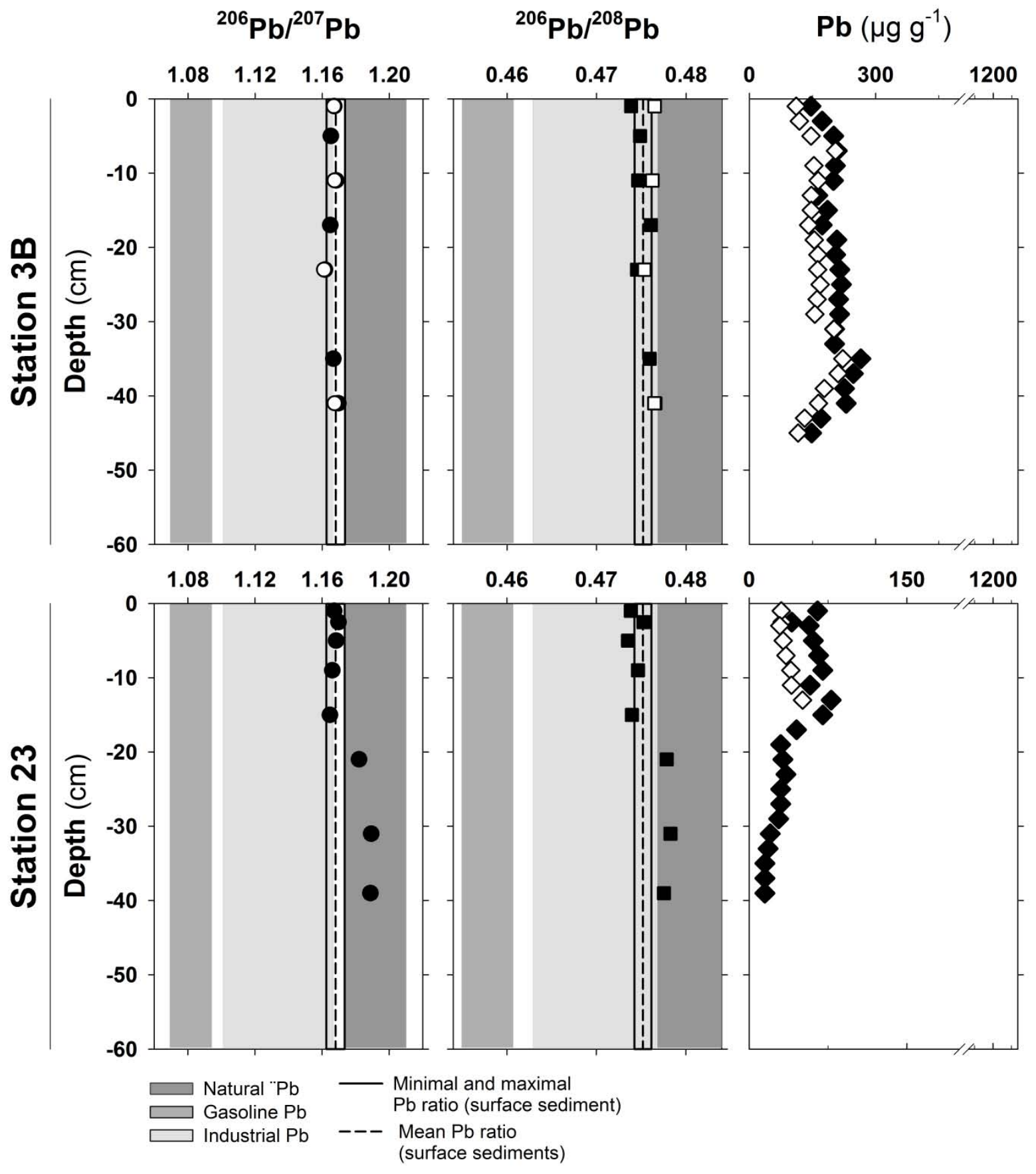


Figure S3: ${ }^{206} \mathrm{~Pb} /{ }^{208} \mathrm{~Pb}$ ratio as a function of ${ }^{206} \mathrm{~Pb} /{ }^{207} \mathrm{~Pb}$ for various $\mathrm{Pb}$ sources observed in the environment (Table A.1). Only the lines limiting the variation of $\mathrm{Pb}$ sources are shown in Figure 4 in comparison to samples from Toulon Bay.

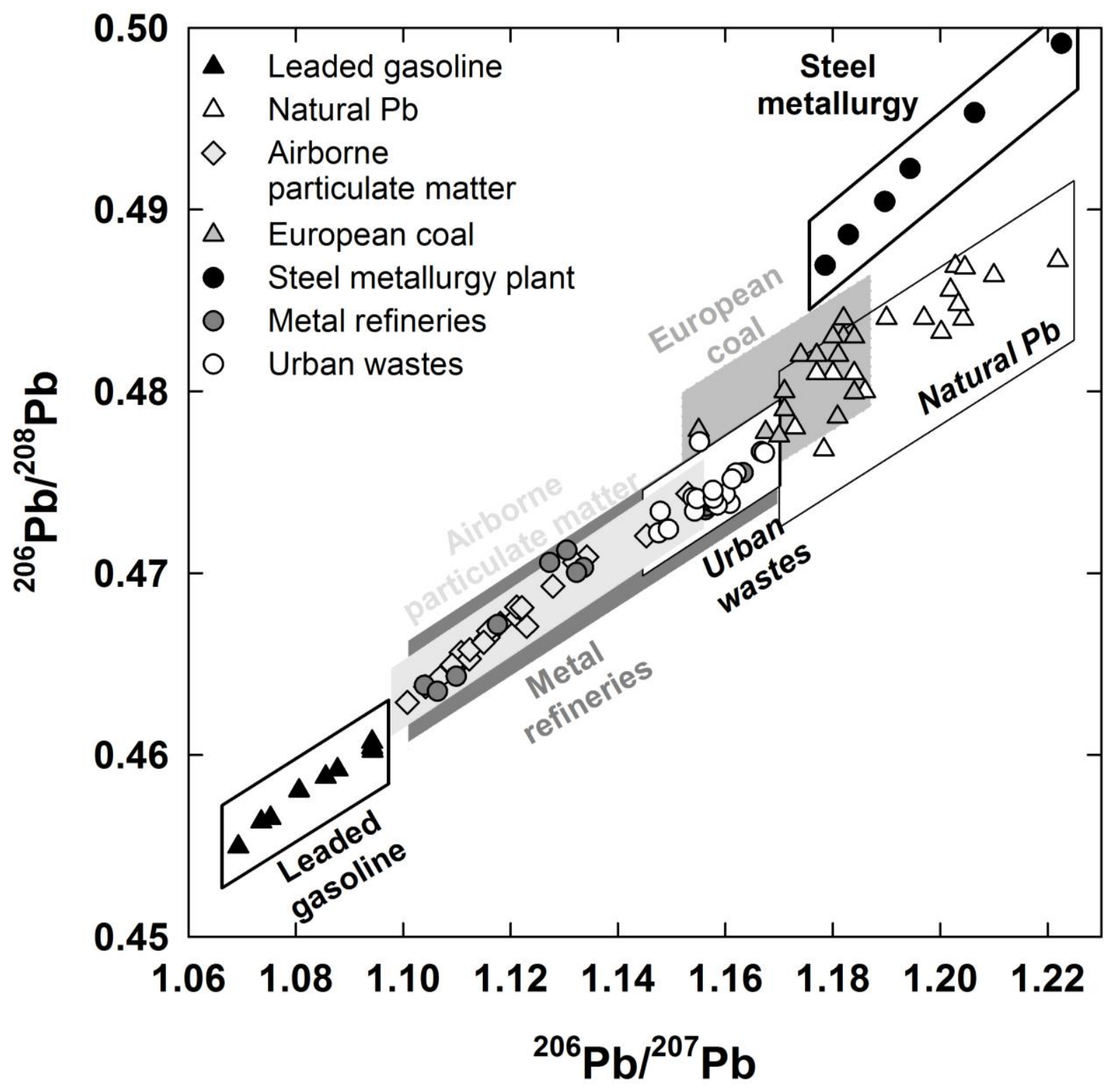


Figure S4: Time variation of $\mathrm{pH}$, dissolved $\mathrm{Pb}, \mathrm{Fe}$ and $\mathrm{Mn}$ concentrations released during sediment resuspension simulation using sediments from stations $3 \mathrm{~B}$ and MIS (surface sediments, $\sim 1 \mathrm{~g}_{\mathrm{dw}} \mathrm{L}^{-1}$ ). The open circles illustrate the initial values measured in seawater. The grey circles represent the contribution of porewater dilution and the black circles represent the measured values at 10 contact times.

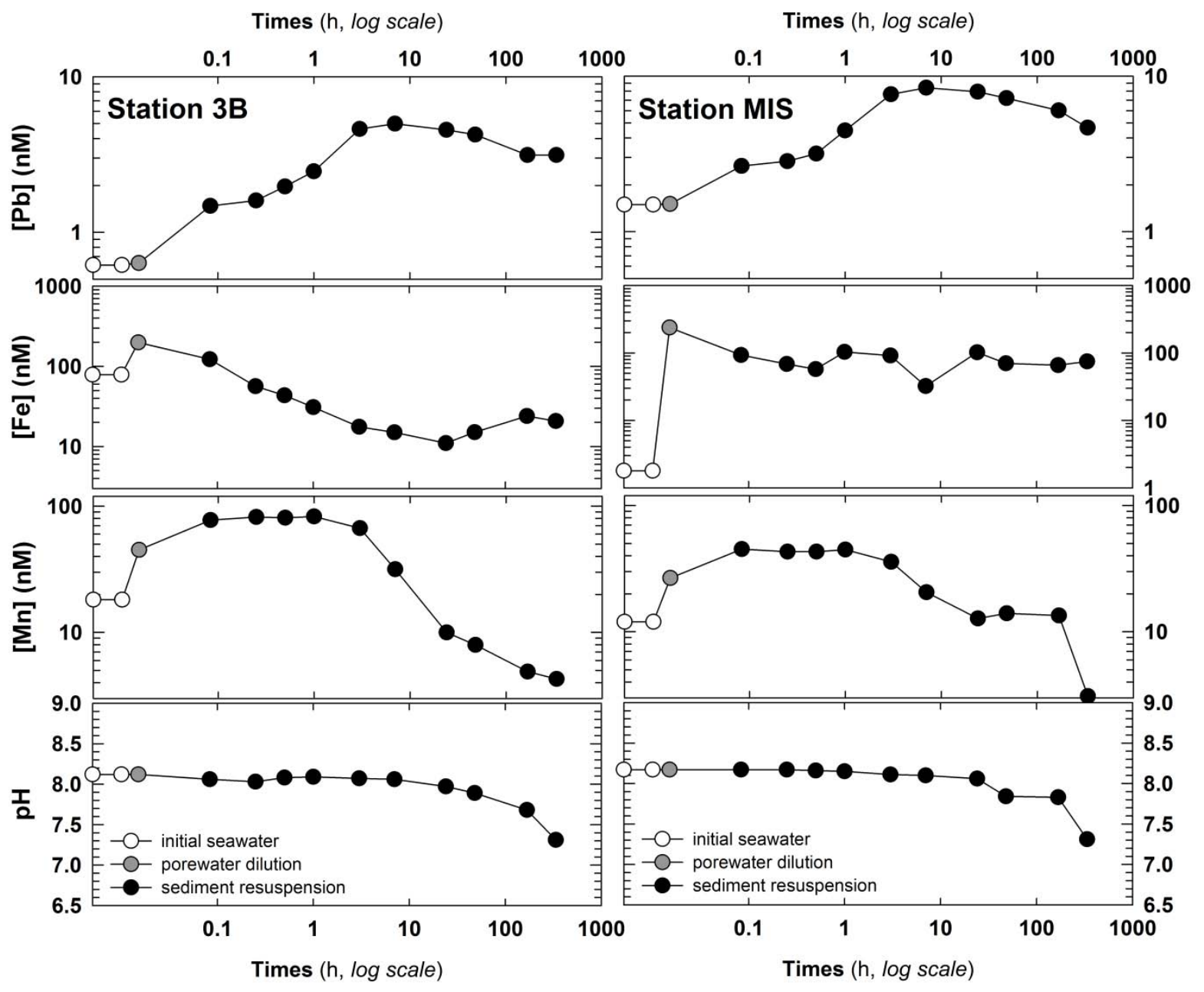


Figure S5: Assessment of the contribution of anthropogenic $\mathrm{Pb}$ source in $\mathrm{Pb}$ contamination of Toulon Bay's surface sediments (see text for more details).

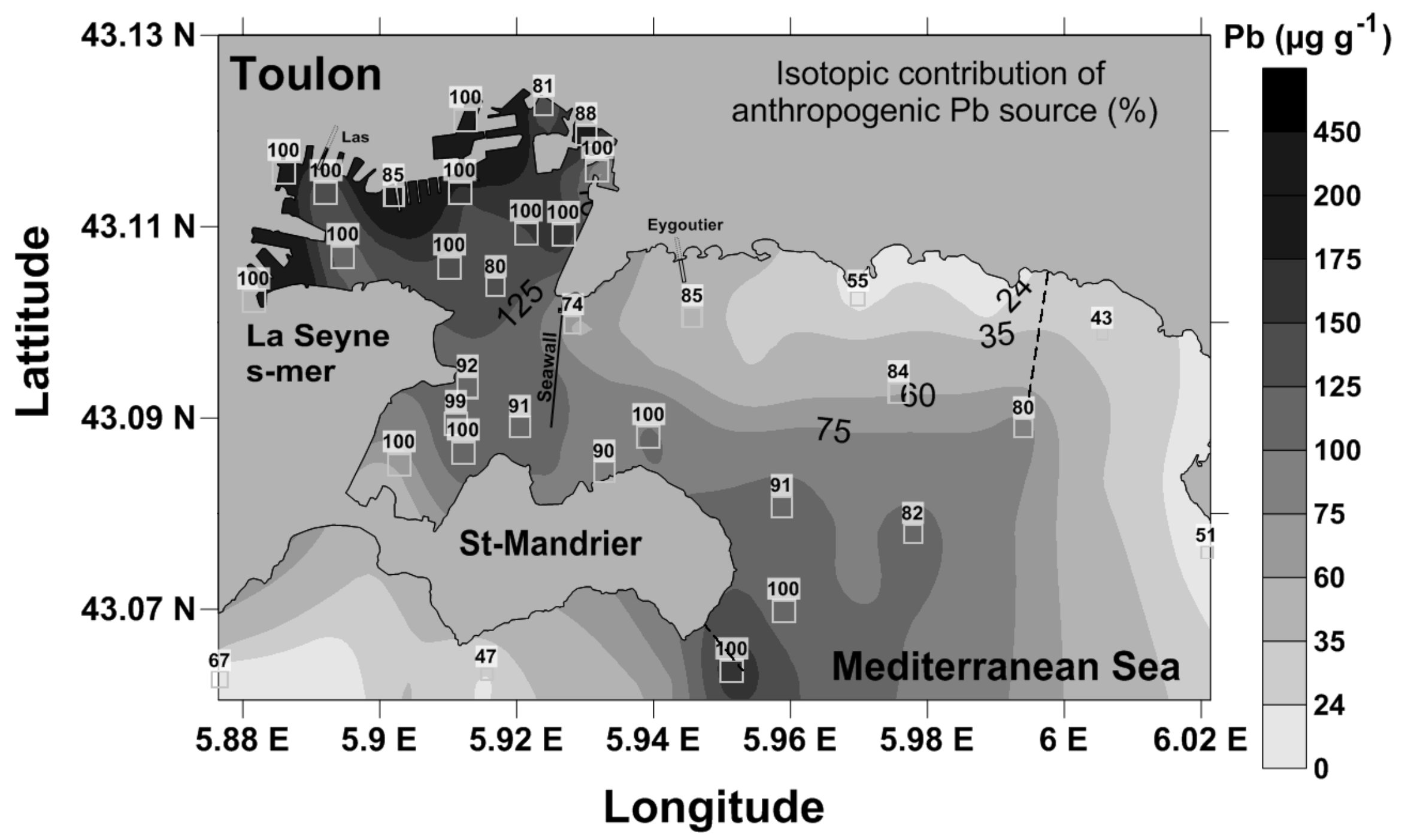


Figure S6: The relationship observed between the total and dissolved $\mathrm{Pb}$ at 40 stations around Toulon bay.

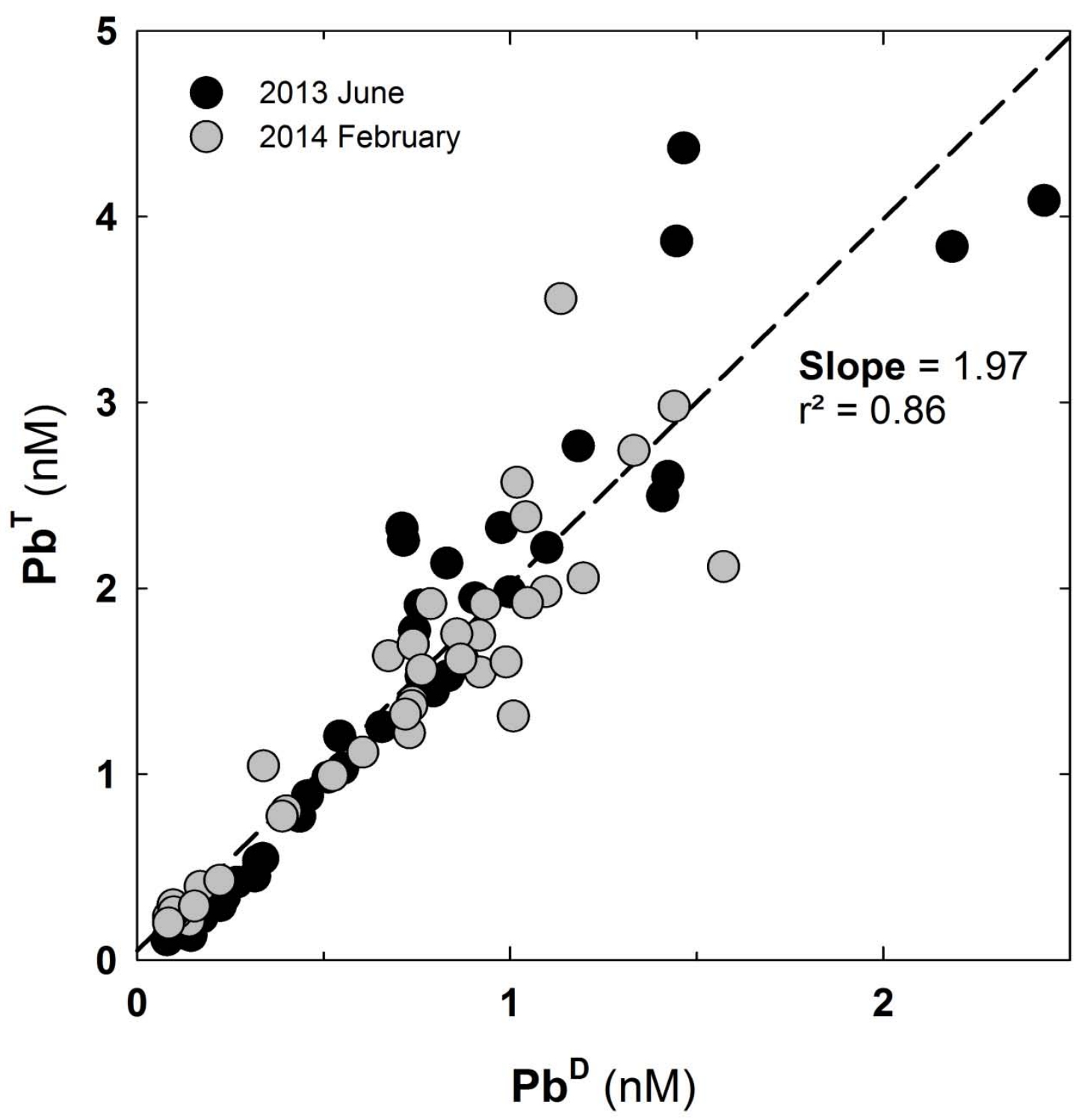




\section{REFERENCES:}

(1) Hamilton, E. I.; Clifton, R. J. Isotopic abundances of lead in estuarine sediments, Swansea Bay, Bristol Channel. Estuar. Coast. Mar. Sci. 1979, 8, 271-278.

(2) Monna, F.; Lancelot, J.; Croudace, I. W.; Cundy, A. B.; Lewis, J. T. Pb Isotopic Composition of Airborne Particulate Material from France and the Southern United Kingdom: Implications for Pb Pollution Sources in Urban Areas. Environ. Sci. Technol. 1997, 31, 22772286.

(3) Harlavan, Y.; Almogi-Labin, A.; Herut, B. Tracing natural and anthropogenic $\mathrm{Pb}$ in sediments along the Mediterranean Coast of Israel using $\mathrm{Pb}$ isotopes. Environ. Sci. Technol. 2010, 44, 6576-6582.

(4) Monna, F.; Othman, D. Ben; Luck, J. Pb isotopes and Pb, Zn and Cd concentrations in the rivers feeding a coastal pond (Thau, southern France): constraints on the origin (s) and flux (es) of metals. Sci. Total Environ. 1995, 166, 19-34.

(5) Chow, T. J.; Patterson, C. C. The occurrence and significance of lead isotopes in pelagic sediments. Geochim. Cosmochim. Acta 1962, 26, 263-308.

(6) Luck, J. M.; Othman, D. B. Geochemistry and water dynamics: II. Trace metals and $\mathrm{Pb}-\mathrm{Sr}$ isotopes as tracers of water movements and erosion processes. Chem. Geol. 1998, 150, 263-282.

(7) Cloquet, C.; Carignan, J.; Libourel, G.; Sterckeman, T.; Perdrix, E. Tracing source pollution in soils using cadmium and lead isotopes. Environ. Sci. Technol. 2006, 40, 25252530.

(8) Véron, A.; Flament, P.; Bertho, M. Isotopic evidence of pollutant lead sources in Northwestern France. Atmos. Environ. 1999, 33, 3377-3388.

(9) Farmer, J.; Eades, L.; Graham, M. The lead content and isotopic composition of British coals and their implications for past and present releases of lead to the UK environment. Environ. Geochem. Health 1999, 21, 257-272.

(10) Chiaradia, M.; Cupelin, F. Behaviour of airborne lead and temporal variations of its source effects in Geneva (Switzerland): comparison of anthropogenic versus natural processes. Atmos. Environ. 2000, 34, 959-971.

(11) De Vleeschouwer, F.; Fagel, N.; Cheburkin, A.; Pazdur, A.; Sikorski, J.; Mattielli, N.; Renson, V.; Fialkiewicz, B.; Piotrowska, N.; Le Roux, G. Anthropogenic impacts in North Poland over the last 1300 years--a record of $\mathrm{Pb}, \mathrm{Zn}, \mathrm{Cu}, \mathrm{Ni}$ and $\mathrm{S}$ in an ombrotrophic peat bog. Sci. Total Environ. 2009, 407, 5674-5684.

(12) Walraven, N.; Os, B. Van; Klaver, G. Trace element concentrations and stable lead isotopes in soils as tracers of lead pollution in Graft-De Rijp, the Netherlands. J.

Geochemical Explor. 1997, 59, 47-58.

(13) D.az-Somoano, M. Stable lead isotope compositions in selected coals from around the world and implications for present day aerosol source tracing. Environ. Sci. Technol. 2009, 43, 1078-1085.

(14) Walraven, N.; van Gaans, P. F. M.; van der Veer, G.; van Os, B. J. H.; Klaver, G. T.; Vriend, S. P.; Middelburg, J. J.; Davies, G. R. Tracing diffuse anthropogenic Pb sources in rural soils by means of $\mathrm{Pb}$ isotope analysis. Appl. Geochemistry 2013, 37, 242-257. 